\title{
Assessment of the Hail Damage on Agricultural Crops from North of Baragan Plain, Romania, Using Remote Sensing Data
}

Claudiu Valeriu Angearu ( $\nabla$ claudiu.angearu@meteoromania.ro )

National Meteorological Administration https://orcid.org/0000-0003-0881-823X

Irina Ontel

National Meteorological Administration

Anisoara Irimescu

National Meteorological Administration

Burcea Sorin

National Meteorological Administration

\section{Research Article}

Keywords: hail, NDVI, LST, SWI, Sentinel, Landsat, weather radar

Posted Date: December 29th, 2021

DOI: https://doi.org/10.21203/rs.3.rs-1180239/v1

License: (a) (i) This work is licensed under a Creative Commons Attribution 4.0 International License.

Read Full License 


\title{
Assessment of the hail damage on agricultural crops from north of Baragan
} 2 Plain, Romania, using remote sensing data

\author{
3 Claudiu-Valeriu Angearu ${ }^{1}$, Irina Ontel ${ }^{1}$, Anisoara Irimescu ${ }^{1}$ and Burcea Sorin ${ }^{1}$ \\ ${ }^{1}$ Remote Sensing and Satellite Meteorology, National Meteorological Administration, 013686 Bucharest, Romania; \\ claudiu.angearu@meteoromania.ro (C.-V.A.); irina.ontel@meteoromania.ro (I.O.); \\ anisoara.irimescu@meteoromania.ro (A.I.); sorin.burcea@meteoromania.ro (S.B.) \\ * Correspondence: claudiu.angearu@ meteoromania.ro
}

\begin{abstract}
Hail is one of the dangerous meteorological phenomena facing society. The present study aims to analyze the hail event from 20 July 2020, which affected the villages of Urleasca, Traian, Silistraru and Căldăruşa from the Traian commune, Baragan Plain. The analysis was performed on agricultural lands, using satellite images in the optical domain: Sentinel-2A, Landsat-8, Terra MODIS, as well as the satellite product in the radar domain: Soil Water Index (SWI), and weather radar data. Based on Sentinel-2A images, a threshold of 0.05 of the Normalized Difference Vegetation Index (NDVI) difference was established between the two moments of time analyzed (14 and 21 July), thus it was found that about 4000 ha were affected. The results show that the intensity of the hail damage was directly proportional to the Land Surface Temperature (LST) difference values in Landsat-8, from 15 and 31 July. Thus, the LST difference values higher than $12^{\circ} \mathrm{C}$ were in the areas where NDVI suffered a decrease of 0.4-0.5. The overlap of the hail mask extracted from NDVI with the SWI difference situation at a depth of $2 \mathrm{~cm}$ from 14 and 21 July confirms that the phenomenon recorded especially in the west of the analyzed area, highlighted by the large values (greater than $55 \mathrm{dBZ}$ ) of weather radar reflectivity as well, indicating medium-large hail size. This research also reveals that satellite data is useful for cross validation of surface-based weather reports and weather radar derived products.
\end{abstract}

Keywords: hail, NDVI, LST, SWI, Sentinel, Landsat, weather radar

\section{Introduction}

In the context of climate change, the risk of weather disasters, such as hailstorms, threaten human well-being by affecting various socio-economical environments. Hail is a form of solid, transparent, or partly or completely opaque precipitation, composed of ice particles, usually spherical, conical or irregular, with a diameter generally between 5 and $50 \mathrm{~mm}$ (WMO 2018). The causes of hail formation are related to the particularities of the general circulation of the atmosphere and those of the active surface. The general circulation of the atmosphere leads to the production of hail through the very active cold fronts that move on the superheated active surface. The local particularities of the active surface trigger the genesis of hail by intensifying the processes of thermal convection and amplifying the degree of air turbulence (Bogdan and Niculescu, 1999). The most favorable conditions occur in summer, due to the intrusion of a cold air mass that displaces the hot air, forcing it to rise rapidly, a phenomenon that causes condensation of water vapor and freezing of raindrops (Balteanu and Alexe 2001).

The potential damages that hailstorm could cause are very well known (Josevski et al. 2013; Kunz and Kugel 2015; Brown et al. 2015; Hoogewind et al. 2017; Prein and Holland 2018; Yue et al. 2019). Due to the high impulse and kinetic energy, hail frequently causes enormous physical damage to crops, vineyards and orchards, and when the size of ice particles exceeds the size of a hen's egg, they can also cause damage to vehicles, buildings, and even injure people (Kunz and Kugel 2015; Prein and Holland 2018). The hail damage loss is directly proportional to the size and frequency of it. For example, in the US, in 2016, the average annual loss from severe convective storms was $\$ 11.23$ billion compared to $\$ 11.28$ billion from hurricanes (Gunturi, P. and Tippett, 2017), registering a peak in June and July in the afternoon hours, in most areas of Europe (Púcik et al. 2019). The vulnerability of crops and their ability to recover after hailstorm depend on the period of the agricultural season, the level of development and maturity of plants (Hillaker and Waite 1985). Also, the extent and intensity of the damage depends on the hail size, the duration of the phenomenon, the wind speed, the type of crop, the development, the maturity of the plant and the time left until harvest (Felix and Kennedy 2007).

The hail phenomenon can be predicted and analyzed, in terms of its effects, based on weather radar information and satellite images. The attempts to identify the agricultural areas affected by hailstorm, using photogrammetric means (color and infrared photograms), have been done since 1969, analyzing the relationship between real vegetation damage and that determined remotely by photogrammetric analysis (Towery et al. 1975). 
Multispectral imagery from remote sensing satellites represent an effective and unique instrument for rapid and precise investigation of natural hazards and it has the potential to provide valuable assistance during damage surveys after severe hailstorm events (Jedlovec et al. 2006).

The effects of hail have been highlighted over time by many specialists who have used various sources of satellite data, for example: GOES-8 satellite data in the case of (Klimowski et al. 1998), Landsat data by (Bentley et al. 2002), (Prabhakar et al. 2019), MODIS data in the study of (Parker et al. 2005; Felix and Kennedy 2007; Gallo et al. 2012), Advanced Very High Resolution Radiometer (AVHRR) data by ( Henebry and Ratcliffe 2002; Parker et al. 2005), Sentinel-2 (Sarvia et al. 2020). Therefore, there are many concerns in finding the best methods to identify and evaluate fast and cheap this phenomenon (Allen et al. 2017).

Hail cannot always be recorded comprehensively by ground-based weather stations, if it occurs outside the spatial extent monitored in-situ. Thus, the weather radars are the only measuring systems providing a large area under constant surveillance and high temporal resolution (Kunz and Kugel 2015). Radar reflectivity can be used to assess and monitor the intensity of precipitation and to infer the precipitation type. The occurrence of hail on the ground that causes severe damage is very likely when the radar reflectivity exceeds a threshold of $55 \mathrm{dBZ}$ (Sandu et al. 2010; Schiesser 1990; Schuster et al. 2006; Carbunaru et al. 2014; Junghänel et al. 2016). However, vegetation damage can be estimated based on multispectral images. These represent a rapid instrument to investigate the natural hazards and they have potential to provide valuable assistance for damage assessment after severe hail storm events (Jedlovec et al. 2006). Photographic images combined with satellite images are often used to identify hail damage by comparing two periods of time before and after the event (Prabhakar et al. 2019). The principle of using satellite data to detect hails damage is based on the premise that strong winds or impact of velocity of huge hails associated can alter the physical characteristics of the impact surface (including especially the vegetation) in such a way so as to produce important changes in visible, infrared or thermal channels (Bell and Molthan 2016; Prabhakar et al. 2019). The defoliation of crops resulted as a combined action of wind and hail contributed to the greatest reduction, almost to a total compromise, whereas strong winds alone may have only toppled the crops and allowed them to survive and recover on their own later, leading to smaller Normalized Difference Vegetation Index (NDVI) changes (Changnon 1967).

In Romania, hail falls frequently in the warm season of the year (April-September), peaking in June. The time of day when the hailstorm occurs is in hot summer afternoons, between 15:00 and 17:00 UTC, when the thermal convection reaches its peak (Burcea et al. 2016).

In the south-eastern part of Romania (Baragan Plain), there are an average of 1-2 cases of hail annually, well below the average of mountain regions (7-8 cases), the damages being much greater in the plain regions due to large agricultural areas (Sandu et al. 2008). The observations from weather stations in Baragan Plain reveal that the hailstorms occur in the time interval 13-15 UTC, having an average diameter between $9-11 \mathrm{~mm}$ and showing an increasing trend of the number of hail cases (Burcea et al. 2016; Cică 2018). Therefore, the main purpose of this study was to identify the best remote sensing methods for assessing the damage caused by hail storms in the Baragan Plain.

The rest of article is structured as follows: section 2 presents a short overview of the weather event, while the third section refers to the data and methods used to analyze the hail event. The fourth section contains the results and discussions with reference to the hail damage and in the last part are the conclusions which emphasize the importance of using satellite data for hail evaluation.

\section{Weather event overview}

The weather event for which the analysis was performed is the hailstorm that occurred on 20 July 2020 in the area of Traian Administrative Territorial Units (ATU), located in the South-East of Romania (Baragan Plain). The study area (Fig. 1) is located in a rural area of 16,416 ha, from which 14,279 ha is occupied by arable land; thus, agriculture is the main activity.

Severe climatic phenomena are the main challenge for agriculture in these areas, being the driest regions of Romania (Angearu et al. 2020), with a significant water deficit during the active crop vegetation period (April-October) (Sandu et al. 2010). In 20 July 2020, between 10:00 and 19:00 UTC, National Meteorological Administration (NMA) issued an orange code warning for most areas of the country (western and southern Moldova, northern Dobrogea, northern and northeastern Muntenia and eastern and southeastern Transylvania). Accentuated atmospheric instability with heavy rain, lightnings, strong winds and hailstorms were forecasted. In that day, the amount of precipitation was expected to reach $30-40 \mathrm{l} / \mathrm{m}^{2}$ and locally $50-60 \mathrm{l} / \mathrm{m}^{2}$.

Precipitation cumulated up to $25 \mathrm{l} / \mathrm{m}^{2}$ between 06:00 UTC 20 July 2020 - 06:00 UTC 21 July 2020 (Fig. 2), being significantly higher compared to the previous period (14-20 July), when the amount of precipitation was below 5 
$1 / \mathrm{m}^{2}$. In the next three weeks in Traian commune there was no average amount of precipitation higher than $0.31 / \mathrm{m}^{2}$, the analyzed area being thus prone to agricultural drought.

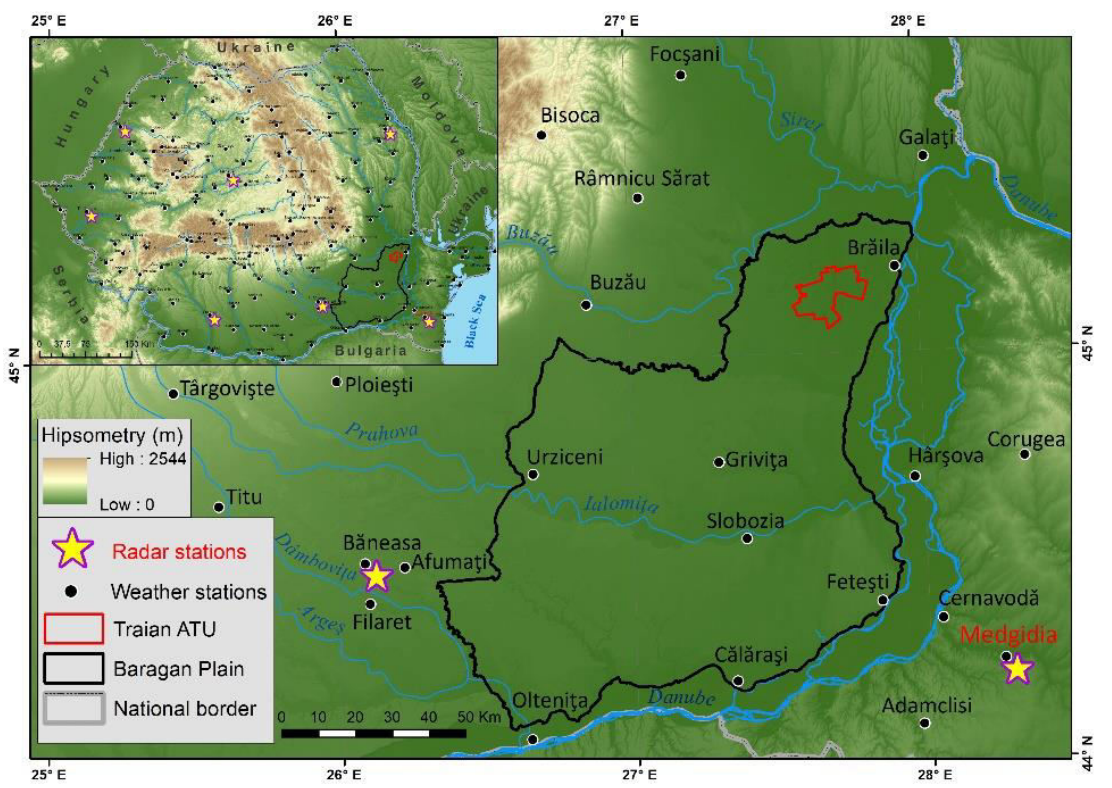

Fig. 1 Position of area of interest, Traian ATU (black polygon) within Baragan Plain, Romania

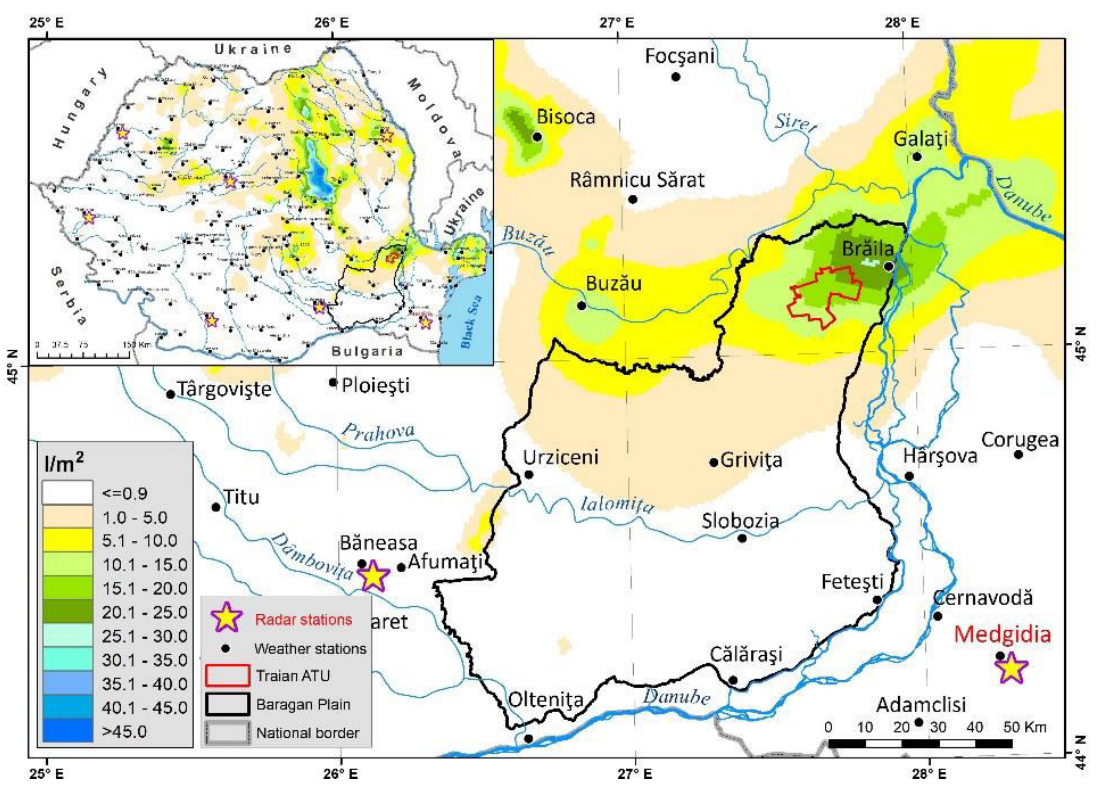

Fig. 2 Spatial distribution of precipitation, 20 July 2020, 06:00 UTC - 21 July 2020, 06:00 UTC. Source: NMA archive

\section{Data and methods 3.1. Data used}

The current study relies on remote sensing data, in order to assess the hail damage on agricultural crops on 20 July 2020 in the Traian ATU (Baragan Plain). Multispectral data from the Sentinel-2 satellite, the Land Surface Temperature (LST) product obtained from the Landsat 8 satellite data, SAR images obtained from the Sentinel-1 satellite and the LST and reflectance products obtained from the Terra MODIS satellite were used (Table 1). Auxiliary data, such as meteorological and Soil Water Index (SWI) products were used to identify the condition of soil moisture before and after the hailstorm. Also, weather radar images were used to identify the hailstorm and Land 
Parcel Identification System (LPIS) were used to identify the land use/land cover types which were damage. The

Table 1 Data and products used

\begin{tabular}{|c|c|c|c|c|c|c|c|c|}
\hline \multicolumn{2}{|c|}{ Type of data } & Product & Satellite & Time period & Unit & $\begin{array}{c}\text { Spatial } \\
\text { Resolution }\end{array}$ & $\begin{array}{c}\text { Temporal } \\
\text { Resolution }\end{array}$ & Data source \\
\hline \multirow{5}{*}{$\begin{array}{l}\text { Input } \\
\text { data }\end{array}$} & \multirow{5}{*}{ Satellite images } & $\begin{array}{l}\text { Multispectral } \\
\text { optical }\end{array}$ & $\begin{array}{c}\text { Sentinel- } \\
\text { 2B }\end{array}$ & $\begin{array}{l}14.07 .2020 \\
21.07 .2020 \\
29.07 .2020 \\
05.08 .2020 \\
08.08 .2020\end{array}$ & $\mu \mathrm{m}$ & $10 \mathrm{~m}$ & 5 days & $\begin{array}{c}\text { Copernicus } \\
\text { Open Access } \\
\text { Hub (ESA } \\
2017)\end{array}$ \\
\hline & & $\begin{array}{l}\text { Land Surface } \\
\text { Temperature }\end{array}$ & $\begin{array}{l}\text { Landsat-8 } \\
\text { TIR and } \\
\text { Aster }\end{array}$ & $\begin{array}{c}15.07 .2020 \text { and } \\
31.07 .2020\end{array}$ & ${ }^{\circ} \mathrm{C}$ & $30 \mathrm{~m}$ & 16 days & $\begin{array}{c}\text { Remote } \\
\text { Sensing Lab } \\
\text { (Parastatidis et } \\
\text { al. 2017), } \\
(2020) \\
\end{array}$ \\
\hline & & $\begin{array}{l}\text { Sentinel-1 } \\
\text { Ground Range } \\
\text { Detected } \\
\text { (GRD) product }\end{array}$ & $\begin{array}{l}\text { Sentinel-1 } \\
\text { C-SAR }\end{array}$ & $\begin{array}{c}10.07 .2020 \text { to } \\
10.08 .2020\end{array}$ & $\mathrm{~dB}$ & $10 \mathrm{~m}$ & daily & $\begin{array}{c}\text { Copernicus } \\
\text { Open Access } \\
\text { Hub } \\
\text { (Parastatidis et } \\
\text { al. 2017) } \\
\end{array}$ \\
\hline & & $\begin{array}{l}\text { MOD09A1 } \\
\text { Surface } \\
\text { Reflectance }\end{array}$ & $\begin{array}{c}\text { Terra } \\
\text { MODIS }\end{array}$ & $\begin{array}{c}04.07 \text { to } 12.08 \\
(2000-2020)\end{array}$ & $\mu \mathrm{m}$ & $500 \mathrm{~m}$ & 8 days & $\begin{array}{c}\text { Earthdata } \\
\text { (EOSDIS 2020) }\end{array}$ \\
\hline & & $\begin{array}{l}\text { MOD11A2(Da } \\
\text { ytime - LST) }\end{array}$ & $\begin{array}{c}\text { Terra } \\
\text { MODIS } \\
\end{array}$ & $\begin{array}{c}04.07 \text { to } 12.08 \\
(2000-2020) \\
\end{array}$ & K & $1000 \mathrm{~m}$ & 8 days & $\begin{array}{c}\text { Earthdata } \\
\text { (EOSDIS 2020) } \\
\end{array}$ \\
\hline \multirow{5}{*}{$\begin{array}{c}\text { Auxiliary } \\
\text { data }\end{array}$} & SAR images & $\begin{array}{l}\text { Soil Water } \\
\text { Index }\end{array}$ & $\begin{array}{c}\text { Sentinel-1 } \\
\text { C-SAR and } \\
\text { Metop } \\
\text { ASCAT }\end{array}$ & $\begin{array}{c}10.07 .2020 \text { to } \\
10.08 .2020\end{array}$ & $\%$ & $1000 \mathrm{~m}$ & Daily & $\begin{array}{c}\text { Copernicus } \\
\text { Global Land } \\
\text { Service } \\
\text { (H SAF 2020) }\end{array}$ \\
\hline & Radar data & $\begin{array}{l}\text { Reflectivity, } \\
\text { storm tracking }\end{array}$ & $\begin{array}{c}\text { S-band } \\
\text { weather } \\
\text { radar }\end{array}$ & 20.07 .2020 & $\mathrm{dBZ}$ & $1000 \mathrm{~m}$ & $\begin{array}{l}\text { Every } 6 \\
\text { minutes }\end{array}$ & $\begin{array}{c}\text { National } \\
\text { Meteorological } \\
\text { Administration } \\
\end{array}$ \\
\hline & $\begin{array}{c}\text { Meteorological } \\
\text { data }\end{array}$ & $\begin{array}{c}\text { Daily } \\
\text { precipitation }\end{array}$ & NA & $\begin{array}{c}10.07 .2020 \text { to } \\
10.08 .2020\end{array}$ & $\mathrm{~mm}$ & $1000 \mathrm{~m}$ & Daily & $\begin{array}{c}\text { National } \\
\text { Meteorological } \\
\text { Administration } \\
\end{array}$ \\
\hline & Land use & $\begin{array}{c}\text { Crop parcel } \\
\text { limits; } \\
\text { Land Parcel } \\
\text { Identification } \\
\text { System (LPIS) }\end{array}$ & NA & 2020 & ha & NA & NA & $\begin{array}{c}\text { Sentinel } 2 \\
\text { images } \\
\text { photointerpreta- } \\
\text { tion; } \\
\text { Agency for } \\
\text { Payments and } \\
\text { Intervention in } \\
\text { Agriculture }\end{array}$ \\
\hline & Photography & $\begin{array}{c}\text { Photo and field } \\
\text { observations }\end{array}$ & NA & 2020 & NA & NA & NA & $\begin{array}{c}\text { Online } \\
\text { newspaper }\end{array}$ \\
\hline
\end{tabular}

According to the mayor of the Traian commune, and the statements of the locals, over 1000 ha of agricultural crops (corn, soybeans, sunflowers, but also vegetables from gardens) have been affected by hailstorm. The hail lasted 1020 minutes, the fields being covered with a layer of ice up to $10 \mathrm{~cm}$ thickness, this further damaging crops (some of them being irrigated - example Căldărușa area - Fig. 3 c) that were already affected by drought (Radio Romania Antena Satelor 2020). Also, according mass-media, it was stated the hail had a diameter of up to $4-5 \mathrm{~cm}$, strongly affecting the agricultural crops, whose damage was estimated at about $€ 608895$ (Valsan 2020; Ferma 2020). It rained with ice the size of a pigeon's egg, especially in the Urleasca and Căldărușa villages, where for some farmers about $80 \%$ of the harvest was compromised, and in some cases even completely destroyed (Ziarul Profit 2020). For example, one farmer who had crops in Urleasca, declared for Agrointeligența-AGROINTEL.ro that the entire crop area is destroyed: "The whole area on Urleasca is compromised, I am not the only one with the calamity crops, they are totally there over $2000 \mathrm{ha"}$ "(Agrointeligenta 2020). The corn was grounded and the crop foliage disappeared as a result of defoliation. In the case of soybean crop, only the stem remained from the plant itself, as a farmer states: the soybean is also affected; it is only the stick of it (Agrointeligenta 2020) (Fig. 3). 

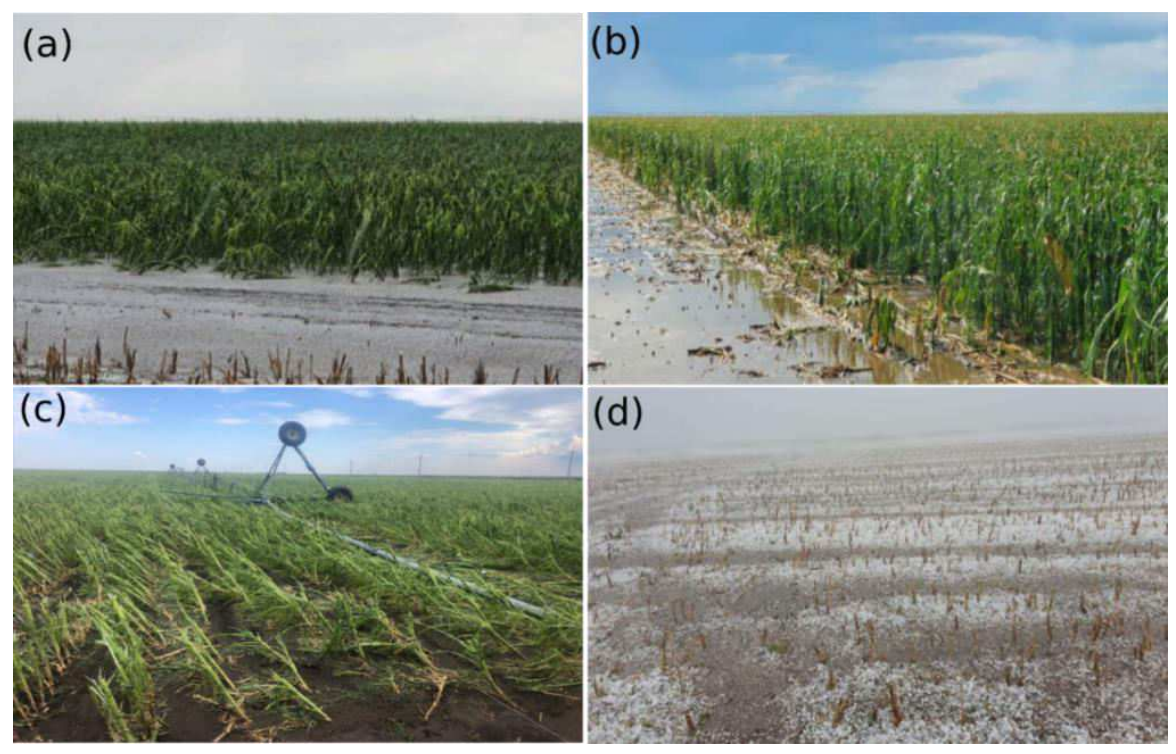

Fig. 3 The hailstorm effects on the vegetation in the Traian area. (a), (b) and (c) the maize crop; (d) soybean.

The locals' gardens were also affected by the fury of nature, the medium-large hail accumulating in a significant layer, as evidenced by the photos posted in the media and social media (Fig. 4).
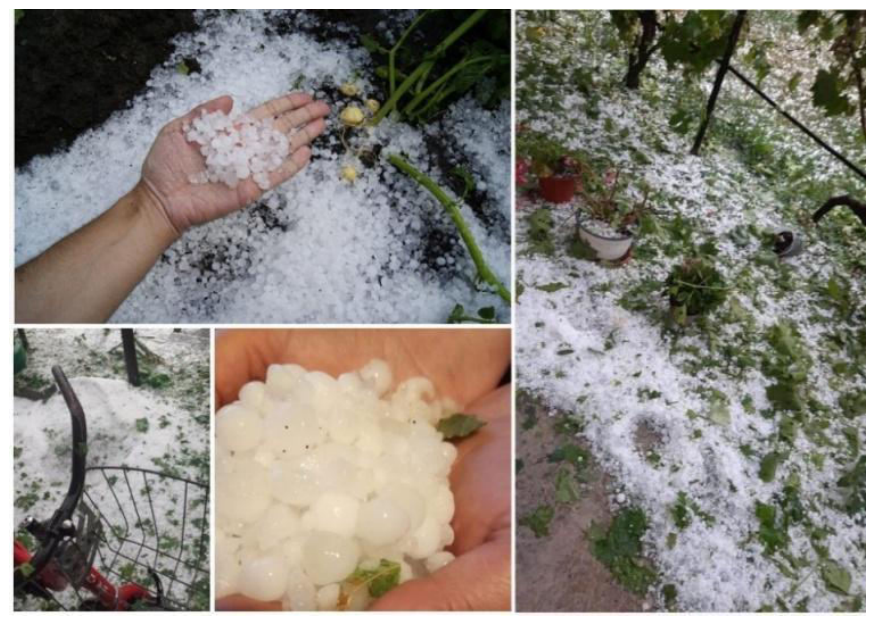

Fig. 4 The effects of hail in the gardens of the locals. Source: (Agrointeligenta 2020)

\subsection{Methods}

One of the most frequently remote sensing indices used for hail analysis is NDVI. The difference ( $\triangle$ NDVI) between two NDVI products (before and after hail) was already used in many other studies (Peters et al. 2000; Bentley et al. 2002; Jedlovec et al. 2006; Felix and Kennedy 2007; Gallo et al. 2012; Molthan et al. 2013); (Prabhakar et al. 2019). However, it is difficult to establish a fixed and general threshold for damage caused by hailstorms derived from the NDVI difference, due to the seasonality of the vegetation (Bell and Molthan 2016). Therefore, the threshold for damage caused by hailstorms is generally set visually, using photointerpretation and expert judgment (Parker et al. 2005) and the results are validated based on radar data or ground truth information as mentioned in the previous studies. For example, (Bell et al. 2020) used the 0.05 NDVI threshold to get the differences between the damaged and background NDVI (undamaged areas). The same NDVI hail threshold was applied by (Sarvia et al. 2020), but they made the NDVI difference between after and before the hail, thus, resulting a negative hail threshold of -0.05 NDVI, admitting that values $<-0.05$ correspond to damaged vegetation pixels. Despite the way the NDVI temporal difference is made (before and after or after and before the hail), it seems that it is necessary a low detailed NDVI 159 threshold to emphasize better the crop damage occurred as a result of unfavorable sudden changes in vegetation. 
While NDVI describes the health of vegetation, Leaf Area Index (LAI) quantifies the amount of leaf material in a canopy, being the ratio of one-sided leaf area $\left(\mathrm{m}^{2}\right)$ per unit ground surface area $\left(\mathrm{m}^{2}\right)$ (Asrar et al. 1984; Myneni et al. 1997). Therefore, LAI is a good indicator of crop defoliation in case of extreme weather events (Wang et al. 2020), but it is less used to identify hailstorms damage (Towers et al. 2019). LAI represents a useful metric for describing both spatial and temporal patterns of canopy growth and productivity. The significance of the LAI comes from the importance of leaves to the plants, which are many and varied. It is also well known that the temperature is higher in areas with bare soil or sparse vegetation (Jackson et al. 1977; Ahmed et al. 2013; Song et al. 2015). Therefore, LST could be higher in areas affected by hail due to crop defoliation.

Vegetation Health Index (VHI) was originally developed to detect vegetation stress as a result of drought conditions. It is based on Vegetation Condition Index (VCI) and Temperature Condition Index (TCI), combining information about the level of vegetation development and also the thermal conditions to which the vegetation is subjected (Kogan 2001; Ma'rufah et al. 2017). Therefore, VHI may have the ability to identify the hailstorm effect on crops, as a consequence of decreasing NDVI and increasing LST. The increase in LST is a result of the decreased albedo in the damaged agricultural lands, allowing more solar radiation to be absorbed by the active surface (Bell 2015). The methodology used in this study is based mainly on change detection between two images (before and after the hailstorm) (Fig.5).

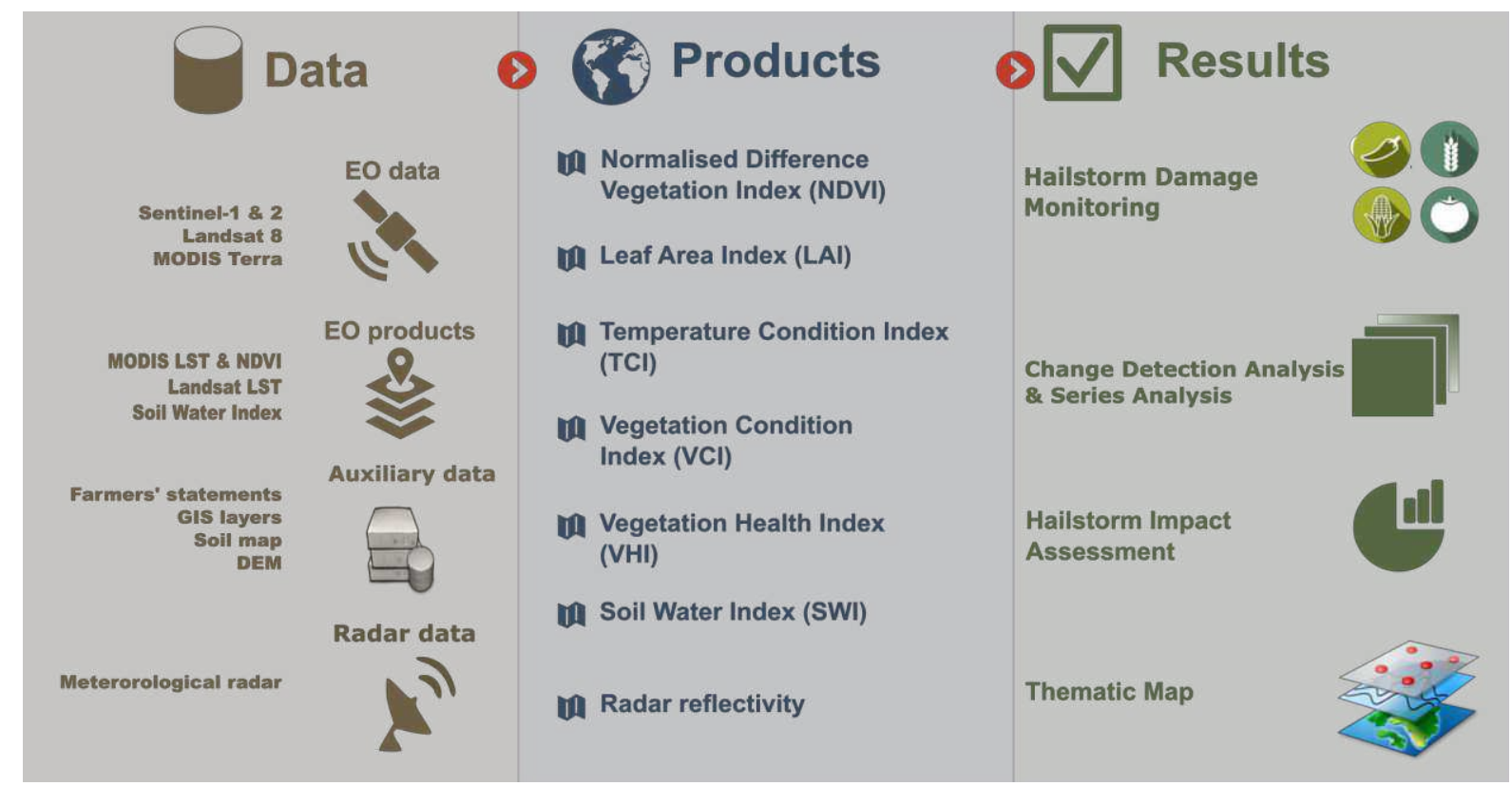

Fig. 5 Workflow for assessment of the damage caused by the hailstorm

The difference in vegetation between the two images is observed even in the case of the natural color combination, with a spatial resolution of $10 \mathrm{~m}$ (Fig.6). Thus, the hail effects at the area of interest (Traian ATU) were detected from the Sentinel-2 L2A multispectral images (level 2 processing), by comparing the vegetation situation before and after the phenomenon occurred, respectively 14 July (09:05 UTC) and 21 July (08:55 UTC). The true color imagery represents a simple and quick way to identify damage to vegetation, as vibrant greens are replaced with colors less greenness or with brown when crops wilt or die and the underlying soils are revealed (Molthan et al. 2013).

However, in order to extract quantitative and qualitative values regarding the damage caused by hailstorm, it is necessary to apply different vegetation indices, respectively statistical methods. Therefore, the NDVI (Rouse J. W . et al. 1974; Tucker 1979) and LAI indices were calculated based on Sentinel-2 data using neural networks algorithm implemented in the Sentinel Application Platform (SNAP), biophysical processor tool (ESA 2020) developed by the European Space Agency (ESA). 


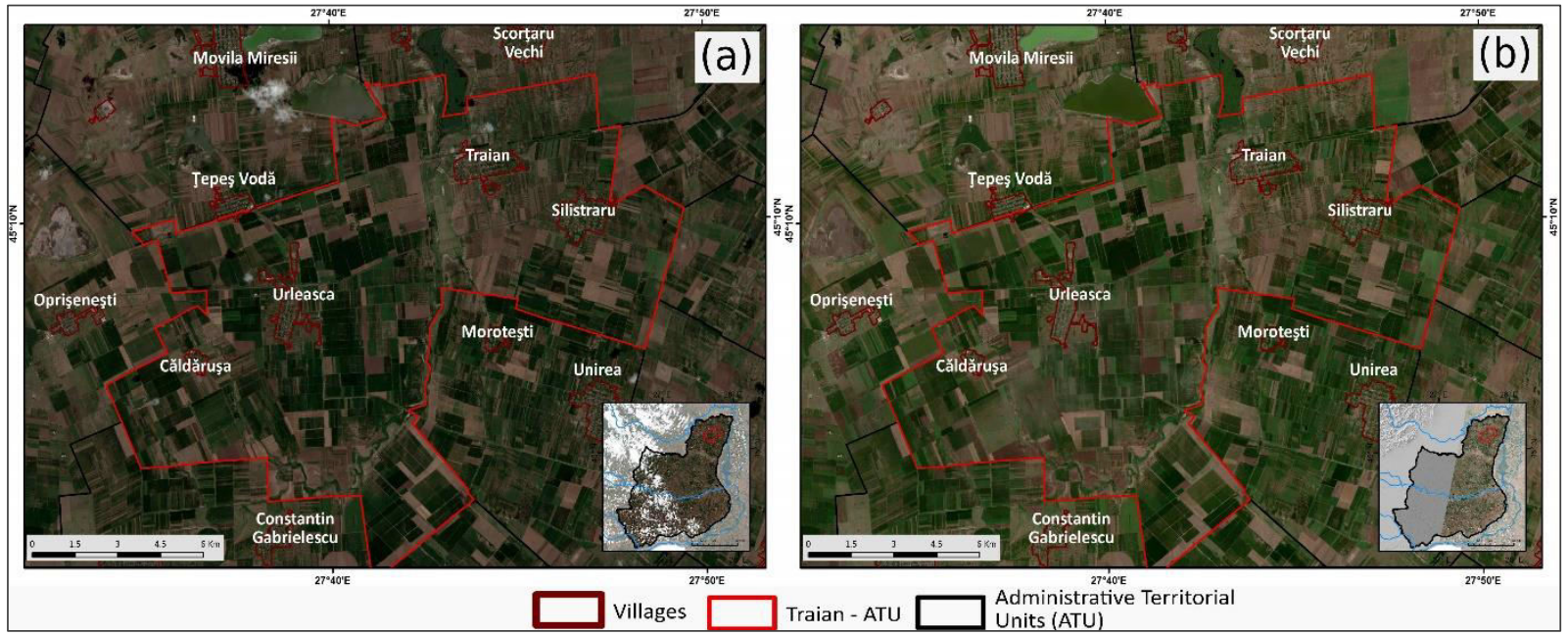

Fig. 6 Sentinel-2 A: (a) 14 July 2020, time 09:05 UTC, (b) 21 July 2020, time 08:55 UTC

NDVI values are between -1 and 1 , negative values representing clouds or water, and positive values close to 0 indicating areas not covered by vegetation (rocks, sands, soil without vegetation, artificial surfaces). Vegetation has positive values: meadows, bushes (rare vegetation) with values between 0.2-0.3, and forests (dense vegetation), respectively the agricultural crops reached maturity have values over 0.6 (Gross 2005). Knowing the different NDVI intervals, we can appreciate the condition of vegetation, the development and growing stages of crops, and the sudden changes of vegetation from our study area. According to (Gallo et al. 2012), the NDVI index obtained from MODIS satellite images seems to be a useful means of validating radar information and those observed in the field, regarding the hail phenomenon (produced in the state of Iowa, on 9 August 2009).

We computed $\triangle \mathrm{NDVI}$ approach $\left(\triangle \mathrm{NDVI}=\mathrm{NDVI}_{\text {pre-event }}-\mathrm{NDVI}_{\text {post-event }}\right)$ to distinguish changes in the vegetation condition over time in the study area. Thus, the NDVI index was calculated from Sentinel-2, according to the equation (1):

$N D V I=(\rho N I R-\rho R e d) /(\rho N I R+\rho R e d)$

where: $\rho N I R$ (band 8) is the near-infrared reflectance, and $\rho$ Red (band 4) is the reflectance in red.

Destructive action of hail on crops is expected to lower NDVI values in damaged fields. Consequently, $\Delta$ NDVI should show positive and negative values for damaged and unharmed fields, respectively. The difference was made between the two NDVI time series (before and after the hail) and the threshold of 0.05 (NDVI>0.05) was chosen to identify the areas affected by hailstorm. The NDVI threshold is positive because all the values greater than 0 pointed out the involution of vegetation condition, the plants suffering from hail, as long as the defoliation leads to the compromise of agricultural crops.

Also, the Otsu's nonparametric method (Otsu et al. 1979) was used to automatically classify the image in two classes as the background and foreground. The background represents the undamaged areas of vegetation and foregrounds that stand out from the background represent the potential hail damage areas in the vegetation (Bell and Molthan 2016). We chose to compare the visual subjective NDVI hail threshold and the function Binary Thresholding (based on the statistical automatic Otsu's method) in order to establish some differences for the intensity and extent of hail. The same operations such as the difference between before and after the hail; the visual threshold of 0.05 and the function Binary Thresholding were applied for the LAI in order to try to emphasize the sensitivity of each other for the hail damage.

LST product (based on Landsat-8 data) was previously downscaled to $30 \mathrm{~m}$ by (Parastatidis et al. 2017) and was downloaded from the Remote Sensing Lab (2020). The difference between the two LST products (before and after the hail) was made. The LST implemented in the web application mentioned above uses a single channel (SC) algorithm (Jimenez-Munoz et al. 2009; Jiménez-Muñoz et al. 2014) to analyses Landsat 5, 7 and 8 thermal infrared observations. SC algorithm approaches are not as efficient as split-window approaches (Yu et al. 2014), but are necessary for satellites acquiring with only one thermal band, like Landsat 5 and (Parastatidis et al. 2017).

Regarding hail analysis based on LST, there are few studies that emphasized on this index. For example, it can be analyzed the single-day LST or the LST anomaly created using two moving kernels (one larger, outer kernel 
representing the background kernel, and one smaller, inner kernel that is differenced against the background to detect the anomalies of surface temperature (Bell and Molthan 2016).

VHI was calculated based on VCI (2) and TCI (3) indices according to the equation (4). The values of the VCI and TCI indices vary from 0 to 100 , reflecting the changes suffered by the vegetation, from extremely unfavorable to optimal (Kogan 1995); (LIU and KOGAN 1996), while low values, close to 0, indicate vegetation stress.

$$
\mathrm{VCI}=100 \frac{N D V I-N D V I_{\min }}{N D V I_{\max }-N D V I_{\min }}
$$

where: NDVI is the value extracted from the synthesis product ( 8 days) for the respective date and $N D V I_{\min }$ and $N D V I_{\max }$ represents the maximum, respectively the absolute multiannual minimum.

$\mathrm{TCI}=100 \frac{T_{\min }-T}{T_{\max }-T_{\min }}$

where: $\mathrm{T}$ is the average value of the temperature extracted from the LST for the respective date, and $T_{\max }$ and $T_{\min }$ the maximum, respectively the absolute multiannual minimum.

$\mathrm{VHI}=\alpha \mathrm{VCI}+\alpha \mathrm{TCI}$

where $\alpha$ is a coefficient considered the equal weight between the two indices and is usually set as $\alpha=0.5$, since the contribution of vegetation and temperature in the vegetative cycle are still unknown (Kogan 2001).

Although VHI was designed to identify the types of drought (VHI values below 40, Table 2), we consider that based on this index it could be analyzed any phenomenon that affects the vegetation, including hail. Therefore, we used it in this study to analyze the surfaces affected by the hailstorm.

Table 2 Types of drought according to VHI (Kogan, 2001)

\begin{tabular}{|c|c|}
\hline VHI & Drought type \\
\hline$<10$ & Extreme drought \\
\hline$\geq 10-<20$ & Severe drought \\
\hline$\geq 20-<30$ & Moderate drought \\
\hline$\geq 30-\leq 40$ & Mild drought \\
\hline$>40$ & No drought \\
\hline
\end{tabular}

It should be noted that NDVI necessary for VCI was computed based on surface reflectance (Red and NIR bands) extracted from MOD09A1 product. It has valid values between -1 and 1 , but in this study a NDVI threshold value greater than 0.2 was used for the vegetation season analysis. Values below 0.2 represent barren soil ( $0-0.2$ interval), as a result of works performed on the agricultural land, such as plowing or harvesting. Also, the NDVI was clipped by the LST because clouds affect the quality of data and could give some erroneous results or bare soil leads to some drought overestimation. The lack of LST data marks the clouds so the vegetation index values are excluded in the VCI computation.

Sentinel 1 data (VH and VV) were pre-processed using SNAP tools: Radiometric Calibrate ->Multilooking (Number of Range Looks: 1) -> Single Product Speckle Filter (Refined Lee) -> Range Doppler Terrain Correction.

SWI product was analyzed, to identify the amount of water in the soil before and after the hailstorm. Regarding the SWI index, each depth level of humidity was multiplied by the scale factor 0.5 , so that the humidity data to be in the range $0-100 \%$. Soil moisture data obtained from satellite images are generally expressed in relative units (\%). This is also the case of the SWI product used in this study. Therefore, the well-known Cumulative Distribution Function (CDF) was used to convert it in volumetric units (Reichle et al. 2004); (Drusch 2005; Liu et al. 2007). CDF-matching was applied to rescale original SWI against GLDAS-Noah soil moisture and it was applied to each individual grid point and based on piece-wise linear matching (Liu et al. 2011).

\section{Results and discussions}

4.1. NDVI

The difference of NDVI between the two images (14 July and 21 July) is significant especially for the agricultural areas (between 0.8 and 0.9 in Fig. 7a, to below 0.6 in Fig. 7b) in the west of Traian ATU. The change detection of NDVI, more exactly the subjective NDVI hail threshold of 0.05 showed that the most the most significant damage were in the west of the Traian commune, especially around the Căldăruşa and Urleasca, were the NDVI recorded generally a decrease higher than 0.25 and locally up to 0.5 (Fig.7).

From the NDVI hail threshold of 0.05 (Fig.8 a) it resulted that approximately 4000 ha were affected by hail (Table 3), mostly the arable land ( $3550 \mathrm{ha}$ ) being damaged. Also, the hail affected vegetable gardens and fruit trees inside 
267 the rural green area included in the area (126.78 ha) (Fig.8 b, c) in the south-west and a smaller area in the north-east 268 (23.27 ha). The vegetation surface included in the rural green area may include local's gardens and small pastures, 269 inside the villages. The results are sustained by reports and photos from the online press and the statements of the 270 locals (Agrointeligenta 2020) accessed at 29.01.2021).

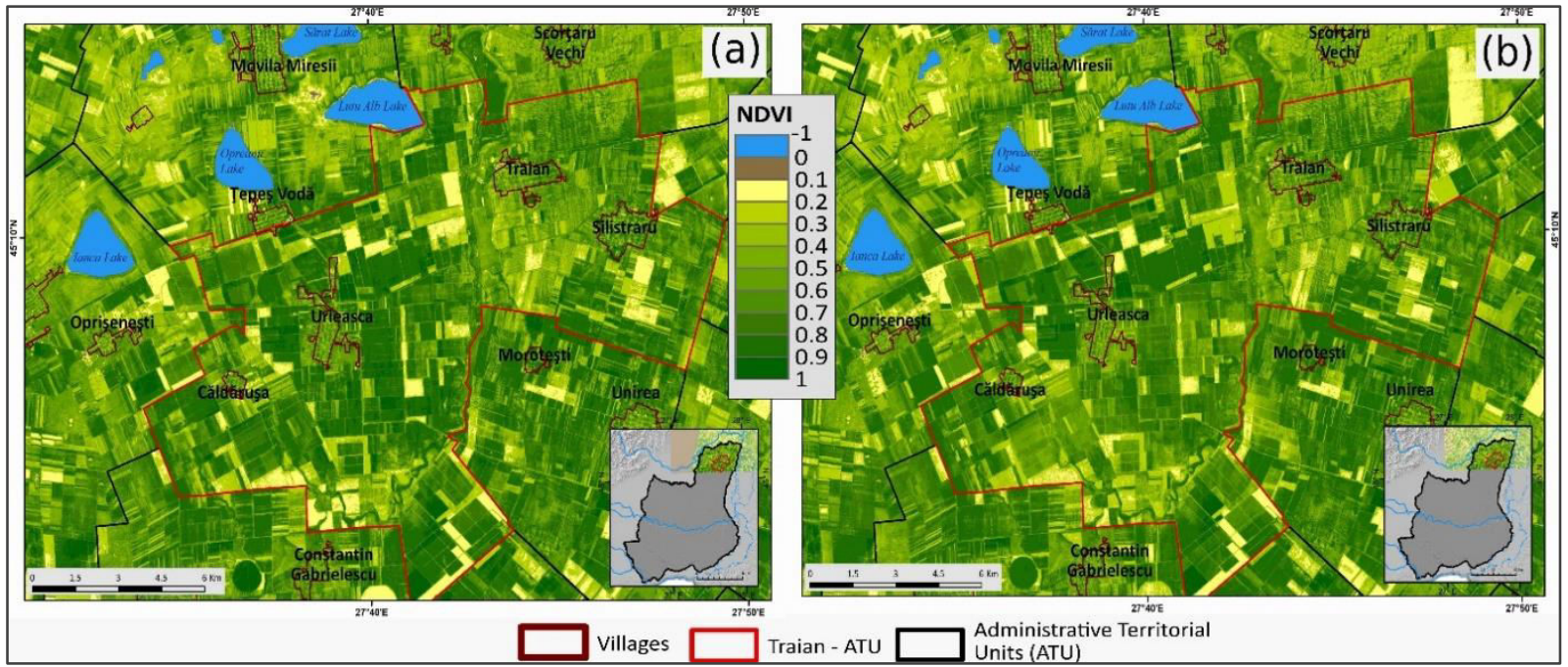

Fig. 7 NDVI (a) 14 July and (b) 21 July 2020.

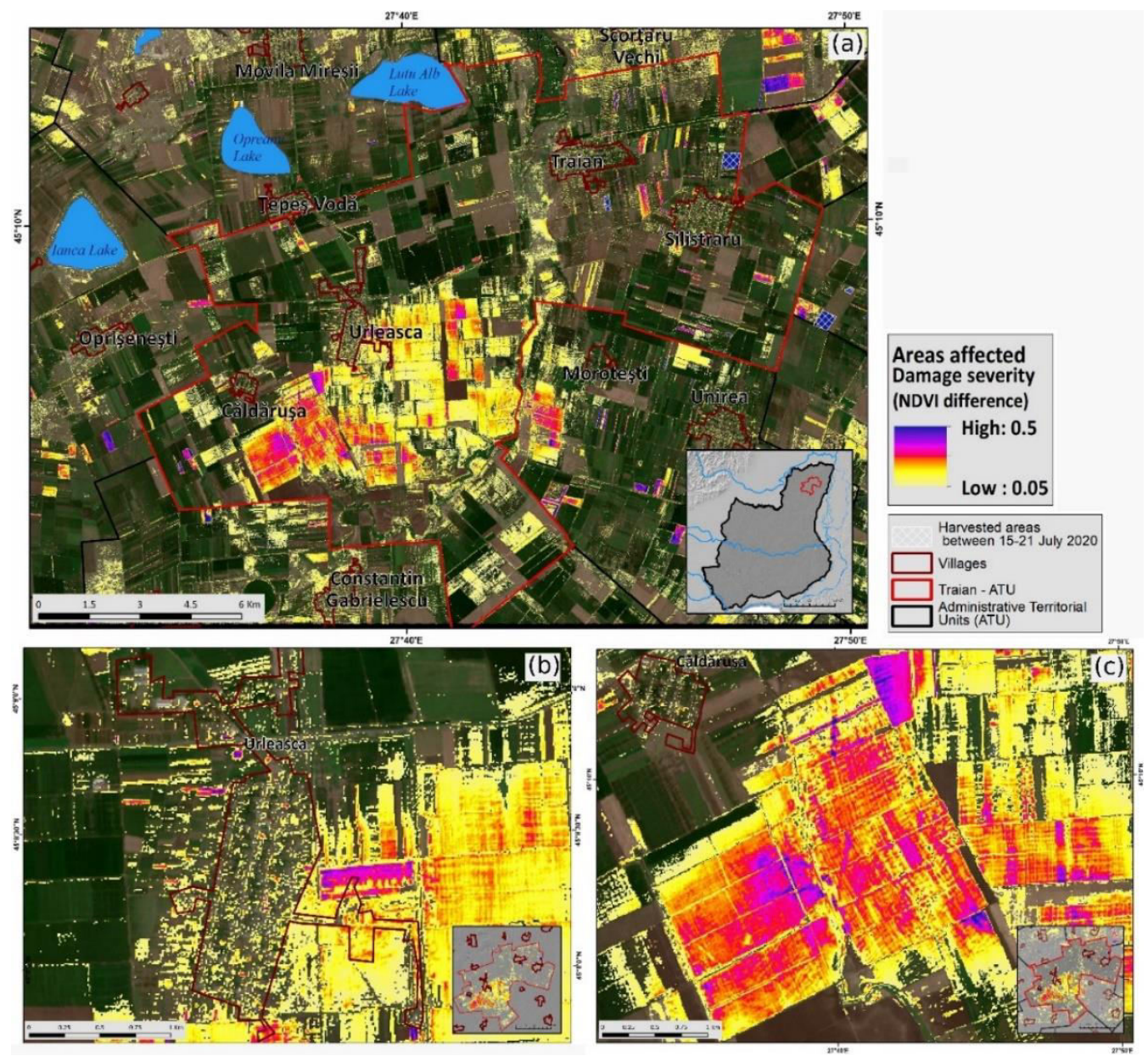

Fig. 8 Hail mask: (a) extracted from the NDVI difference 14-21 July 2020; Affected areas: (b) Urleasca; (c) Căldăruşa 
Table 3 Agricultural land affected by hail according to NDVI

\begin{tabular}{|c|c|c|}
\hline Land use & $\begin{array}{c}\text { Affected surface } \\
\text { (ha) }\end{array}$ & $\begin{array}{c}\text { Affected } \\
\text { surface (\%) }\end{array}$ \\
\hline Arable land & $3.550,02$ & 90.50 \\
\hline Pasture & 236.86 & 6.03 \\
\hline Gardens, agricultural lands inside the rural green area & 126.78 & 3.23 \\
\hline Fruit trees and berry plantations & 7.44 & 0.18 \\
\hline Vineyards & 1.4 & 0.03 \\
\hline Totally surface considered as affected & $\mathbf{3 9 2 2 . 5}$ & 100 \\
\hline
\end{tabular}

\subsection{NDVI and LAI hail mask comparison}

Both positive difference $\triangle$ NDVI and $\triangle$ LAI highlight very well the negative changes suffered by the vegetation after the hail event, the west of the Traian ATU being seriously affected (Fig.9 a-b), especially for and around the Urleasca and Căldăruşa villages. The 0.05 threshold applied for $\triangle$ NDVI and $\triangle$ LAI emphasizes better the hail damage extent (Figure $9 \mathrm{c}-\mathrm{d}$ ). Comparing the results obtained with the Binary Thresholding Function based on Otsu's method, it turned out that the extent of hail is considerably limited for LAI (Fig. $9 \mathrm{f}$ ) than the NDVI, which seems to overestimates the hail extent (Fig. 9 e). Considering the results obtained by the two methods ( $\triangle$ NDVI and $\Delta$ LAI, followed by a visual subjective hail threshold, respectively the Binary Thresholding Function) it can be clearly say that the hail affected especially the crops from Urleasca and Căldăruşa villages and overall the hail produced damages between 2000 and 4000 ha (Fig. 10).

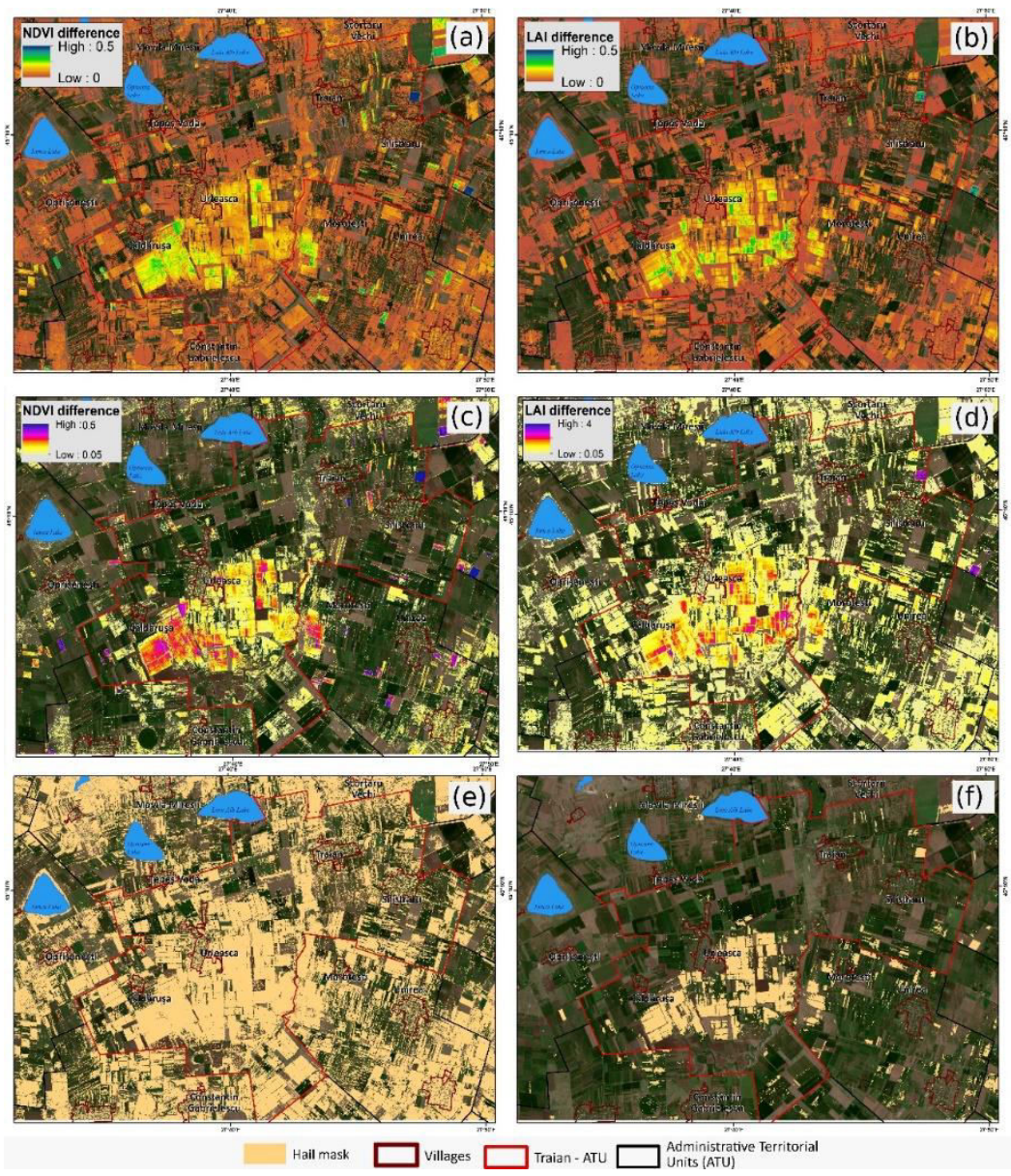

Fig. 9 NDVI and LAI difference between 14 and 21 July 2020: (a) and (b) positive difference; (c) and (d) positive difference with a subjective hail threshold of 0.05; (e) and (f): Binary Thresholding Function based on Otsu's method for: (e) NDVI; (f) LAI difference between 14 and 21 July 2020 


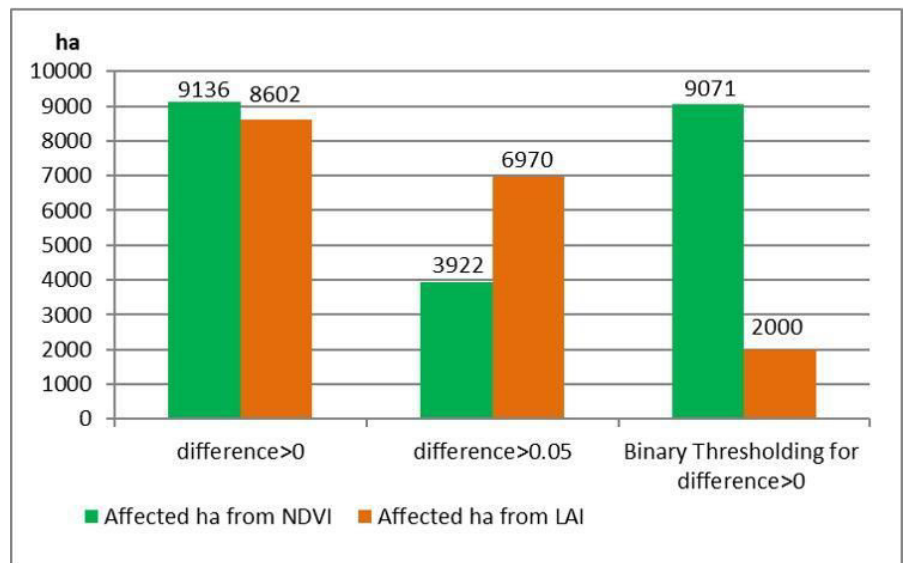

Fig. 10 Surfaces (ha) affected by hail in Traian ATU, according to the NDVI/LAI difference between 14 and 21 July 2020

Considering that NDVI hail mask extent, based on the visual threshold, is more suitable than the LAI, we chose to compare both indices evolution with the extend derived from 0.05 NDVI threshold, in order to evaluate the hail damages. Another reason why we chose NDVI as hail mask for further several analyzes, instead of LAI, is that NDVI has been widely used for the hail analysis, so we decided to monitor the agricultural land affected by this dangerous meteorological phenomenon only for the Traian ATU.

Also, we tried to analyze the damages for the type of crops (eg. corn, sunflower, soybean etc.) identified on the satellite imagery, considering also the photos taken from the field and the declaration of the authorities and locals.

One first result was that the correlation between NDVI and LAI has a Pearson coefficient of 0.99, meaning that both identified the hail damage in the same manner, both indices decreasing with the defoliation of vegetation after 20 July 2020 (Fig. 11).

Fig. 11 NDVI and LAI correlation for the agricultural lands affected by hail in the Traian ATU

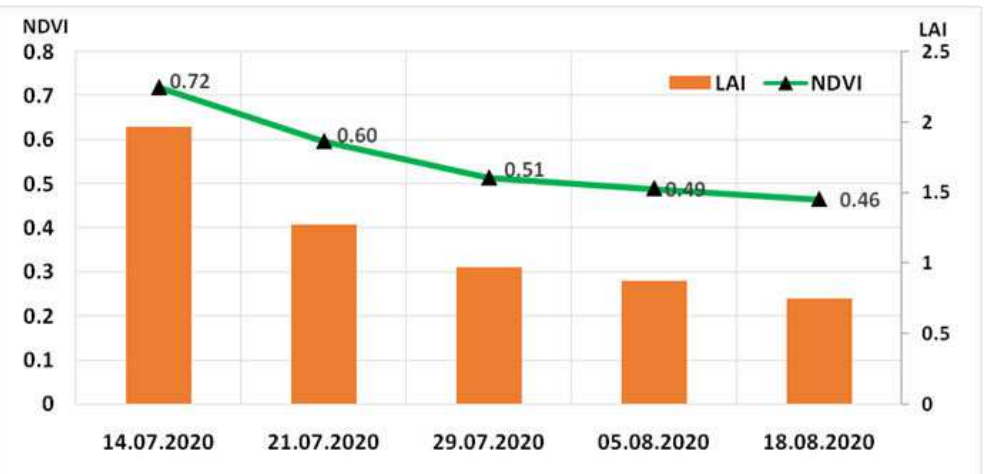

Another result relates to the fact the NDVI values in the areas affected by hail have not improved during the next days and weeks. Thus, they have dropped from 0.72 to 0.60 (one day after) and 0.51 (on 29 July). Vegetation continued to suffer in August, but with a lower decreasing trend compared to previous time series (Fig. 12).

To analyze the damage for agricultural crops we decided to remove the harvested areas from the hail mask based on the 0.05 NDVI threshold. To identify the type of crop we used the photointerpretation based on the Sentinel-2 images, from May to August (Fig. 13). The harvested crops (eg. winter wheat, rape) were observed with few weeks before the hail event, so these areas were excluded from a damage assessment. In the case of pastures, vineyards, fruit trees and berry plantations we used the LPIS 2020 to analyze the effects of hail. Thereby, from the 3922 ha of agricultural lands extracted from NDVI hail mask, only 3142 ha were considered for the unharvested crops (Table 4). It is necessary for the unharvested crops to be evaluated and monitored in order to make future connections between the effects of hail, the decrease of agricultural productions and the compensation of the insured farmers.

With regard to the harvested crops overlapped on the hail mask, it should be noted that $\triangle$ NDVI has high values (0.40.5 ) because some of these crops were harvested with a long time before the hail occurrence, so the weeds started to grow, being improved over time and then after the hail event it suffered enormously. Even these harvested vegetation areas suffered after the hailfall, these crops are no longer of interest for the farmers. 

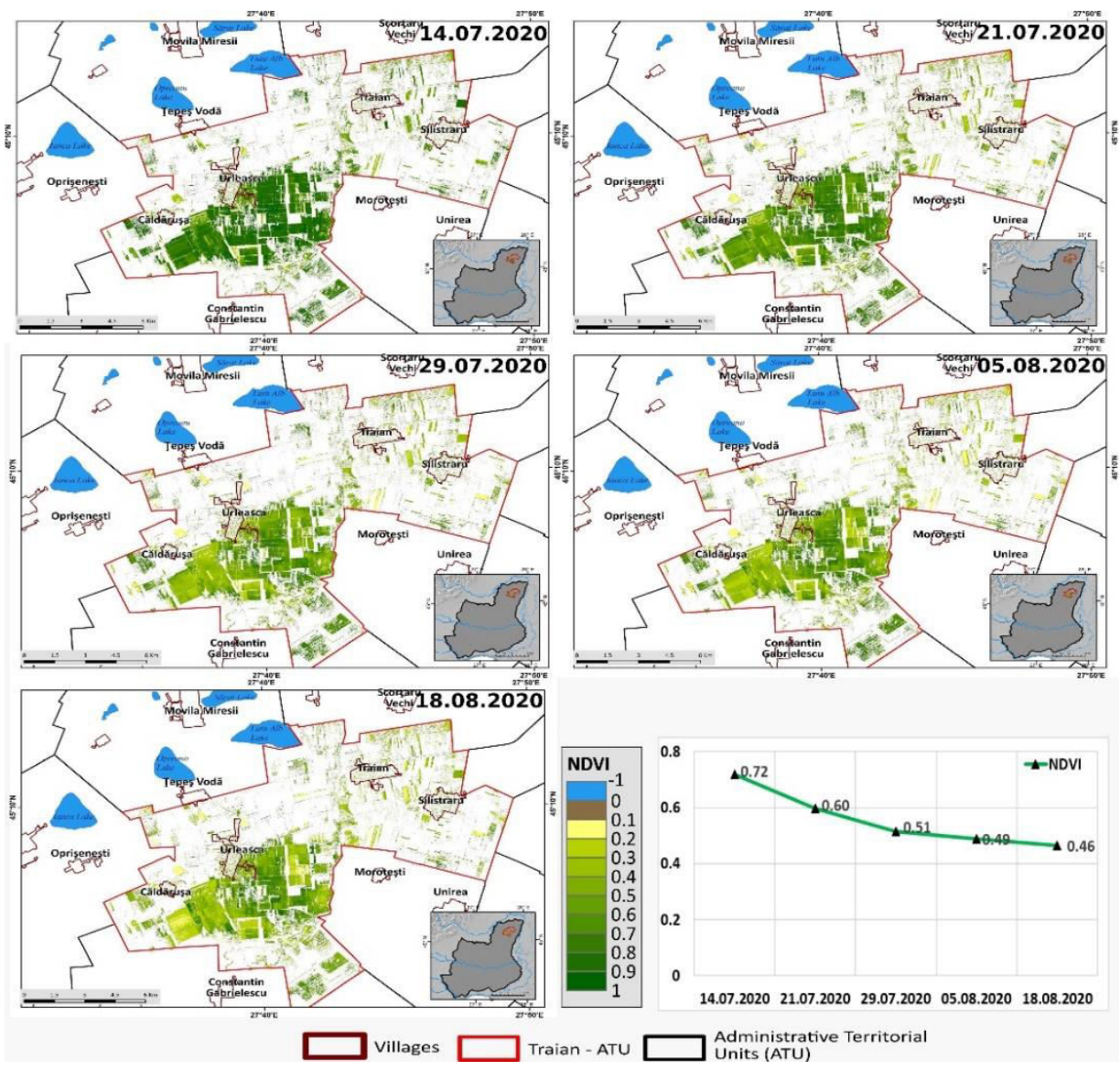

Fig. 12 The NDVI evolution of the areas affected by hail between 14 July and 18 August 2020

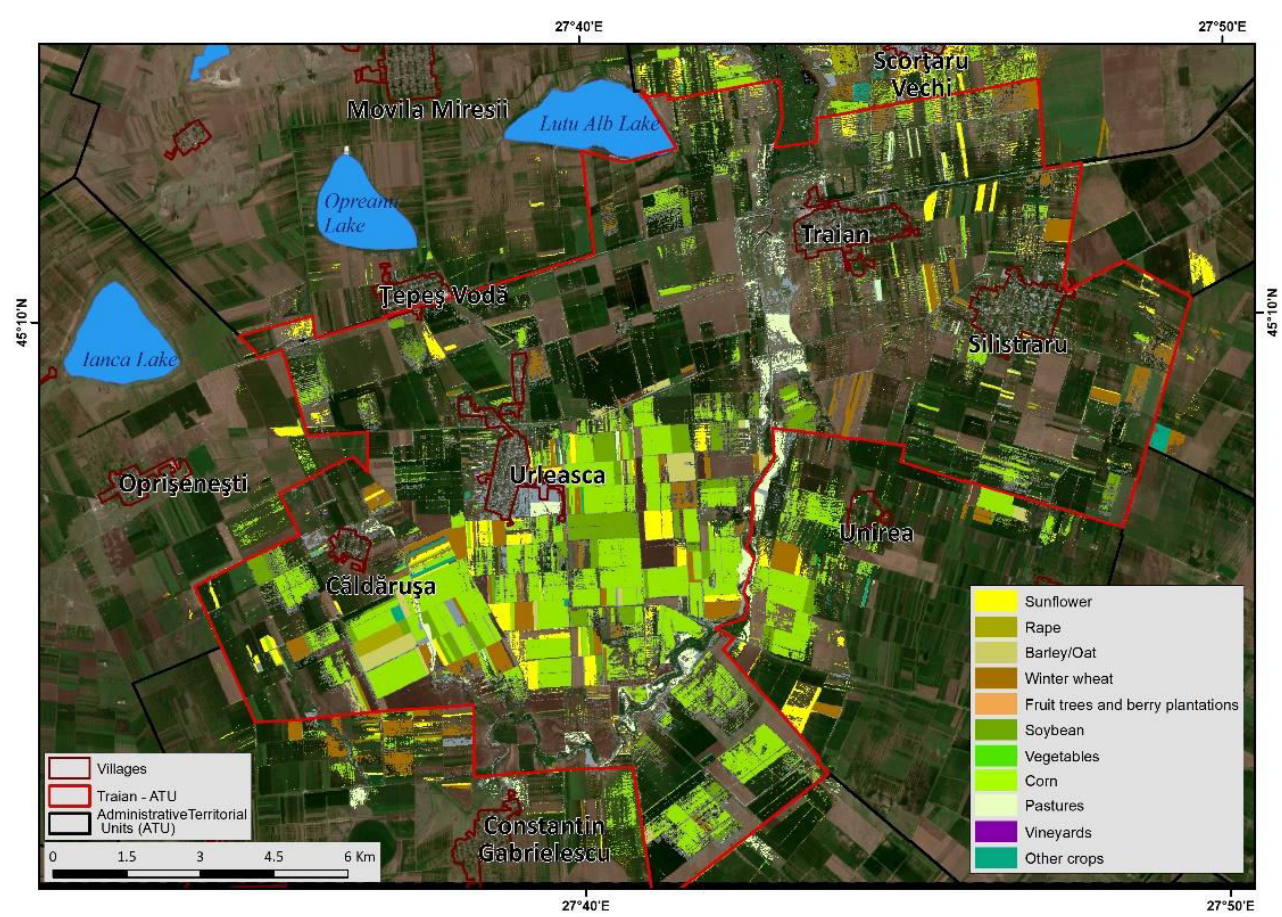

Fig. 13 Hail damage for agricultural crops in Traian commune 
Table 4 Hail damage for agricultural crops in Traian commune

\begin{tabular}{|c|c|c|}
\hline Crop type & $\begin{array}{c}\text { Affected } \\
\text { surface (ha) }\end{array}$ & $\begin{array}{c}\text { Affected surface from the } \\
\text { totally unharvested crops } \\
(\%)\end{array}$ \\
\hline Corn & $2.134,78$ & 67.92 \\
\hline Soybean & 90.93 & 2.89 \\
\hline Sunflower & 93.56 & 2.98 \\
\hline Pastures & 236.86 & 7.54 \\
\hline $\begin{array}{c}\text { Gardens, agricultural lands } \\
\text { inside rural green area }\end{array}$ & 126.78 & 4.03 \\
\hline $\begin{array}{c}\text { Fruit trees and berry } \\
\text { plantations }\end{array}$ & 7.44 & 0.24 \\
\hline Vineyards & 1.40 & 0.04 \\
\hline Other crops (undefined) & 451.23 & 14.36 \\
\hline Totally unharvested crops & $\mathbf{3 . 1 4 2 , 9 8}$ & 100 \\
\hline Totally harvested crops & $\mathbf{7 7 9 . 5 2}$ & \\
\hline $\begin{array}{c}\text { Totally surface considered as } \\
\text { affected }\end{array}$ & $\mathbf{3 9 2 2 . 5}$ & \\
\hline \multicolumn{2}{|l}{} \\
\hline
\end{tabular}

By correlating the NDVI and LAI, it is possible to better understand the way in which the state of vegetation evolved after the hail event. On 14 July 2020, before the hailstorm, the soybean had the highest NDVI and LAI values from the types of crops analyzed (corn, sunflower, soybean), followed by the sunflower and corn.

After the hailstorm, on 21 July 2020, the NDVI and LAI values significantly decreased for the corn and sunflower, these crops continued to suffer more than the soybean in the next period. So, if on 14 July, the NDVI for corn had a value of 0.78 , on 21 July decreased to 0.74 , registering a loss of $15.58 \%$. On $29 \mathrm{July}$, the corn affected by hail had a NDVI value of 0.54 and a loss of $17.37 \%$ compared with the 21 July (Fig. 14). Compared with the NDVI results, the LAI pointed out a higher increase of the loses (in some cases even over to half) suffered by the crops for the entire selected interval (Fig.15). The LAI difference between 14 and 21 July marks a loss of $33.65 \%$ in the case of corn, whereas the NDVI registered a loss of $16.35 \%$. For the sunflower the LAI had a loss of $29.54 \%$, whereas the NDVI only $13.86 \%$. Regarding the soybean the least sensitive to hail, the LAI had a loss of $15.58 \%$ and the NDVI registered 9.37\%. For 21-29 July difference, the LAI continued to have high loses for corn $(25.36 \%)$ and sunflower $(18.52 \%)$, whereas for the next time difference (29 July-08 August), the soybean registered higher losses (16.38\%), than the other two crops.

In the case of the 8-18 August difference, the LAI soybean reached the highest loss of -30.58\% during the time series analyzed, whereas the NDVI marks a loss of $15.15 \%$. The evolution of LAI and NDVI losses for the soybean during the interval selected highlights the idea that soybean was less affected and the process of biophysical degradation was not so significant as in the case of corn and sunflower. As a conclusion, it can be said that sensitivity of LAI it seems to be a good indicator for estimating the losses of vegetation condition for different crops.

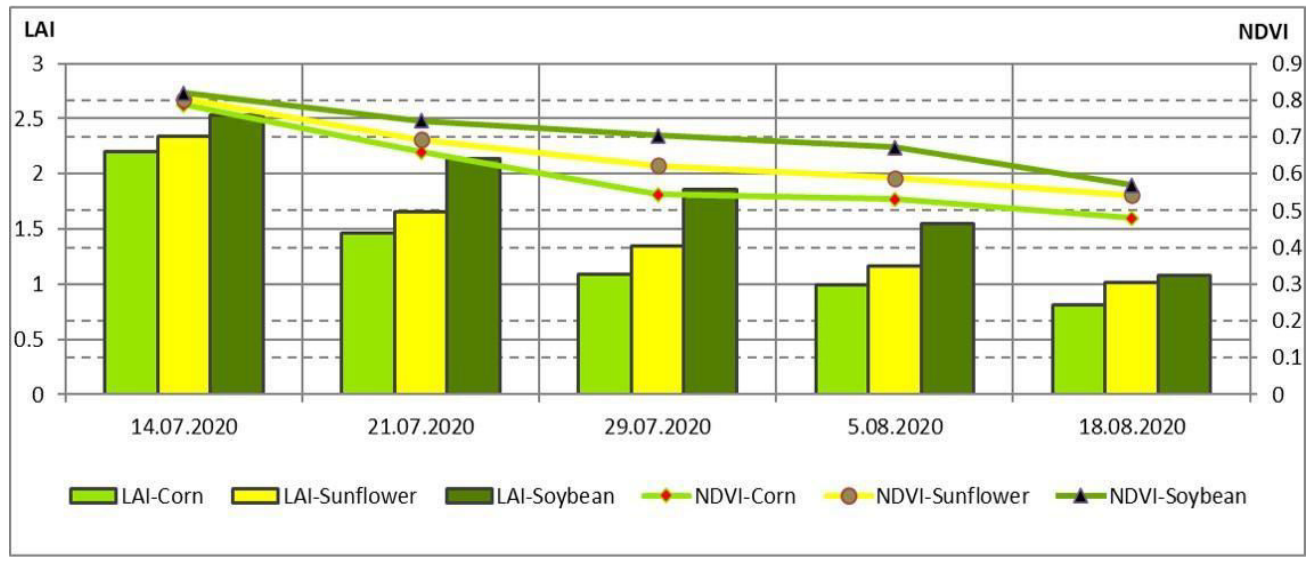

Fig. 14 Evolution of LAI and NDVI for crops affected by hail in Traian ATU 


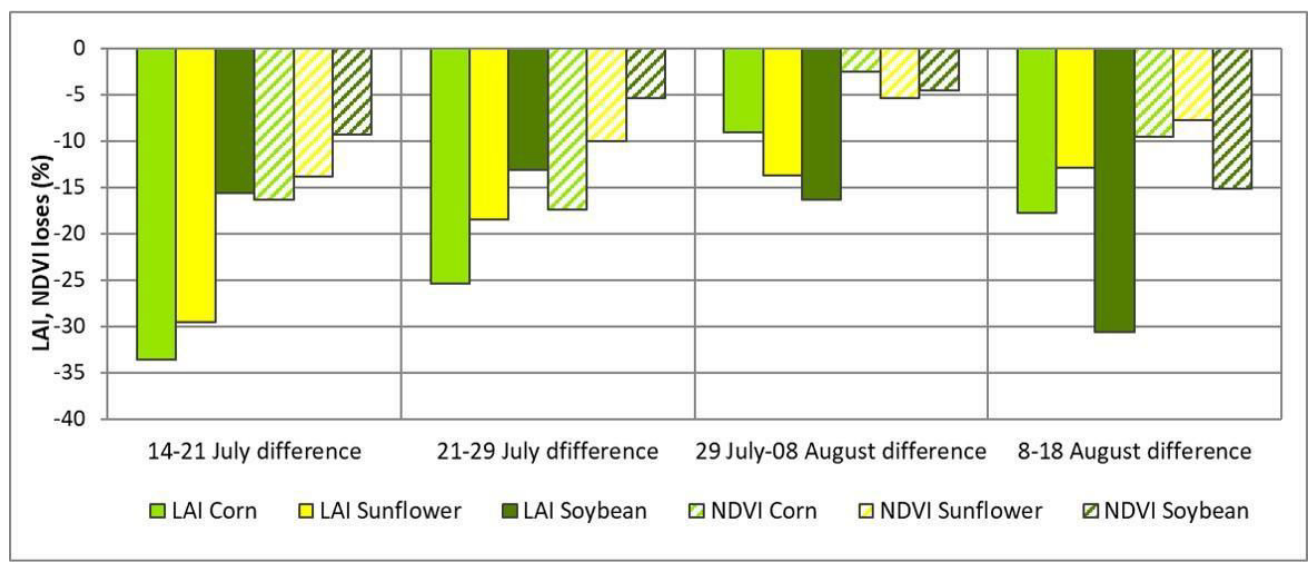

Fig. 15 Losses of vegetation condition according to LAI and NDVI for crops affected by hail in Traian ATU

Regarding the LST, this index can represent a useful tool or even a method (based on either a temporal difference, different percentile interval, standard deviation, or on index such as the TCI) to emphasize the intensity and extend of the hailfall.

The damage registered at the level of agricultural lands was significant enough that it determined the increase of the LST (Fig. 16) registered after the extreme phenomenon. In the areas most affected by hail, the differences between the LST values, from 15 to 31 July 2020, are higher than in the surrounding areas. Temperatures increases were generally found between $8-12^{\circ} \mathrm{C}$, followed by those in the range of $4-8^{\circ} \mathrm{C}$ and $12-16^{\circ} \mathrm{C}$, respectively. LST values are higher than in the surrounding areas, because soils with very sparse vegetation, with crops that have lost even all their foliage, but especially almost bare soils, not covered by vegetation, heat up faster than in the areas with unaffected vegetation. The average LST for the affected area was $38.27^{\circ} \mathrm{C}$ on $31 \mathrm{July}$, compared to $30.48^{\circ} \mathrm{C}$ on 15 July 2020, thus registering a difference of $+7.79^{\circ} \mathrm{C}$. Regarding the extreme's temperatures, they were between 16$18^{\circ} \mathrm{C}$ and were recorded southwest of the Urleasca village (Figure 17a). It was also observed that the intensity of the hail damage was directly proportional to the LST values. Thus, the LST difference values higher than $12^{\circ} \mathrm{C}$ were in the areas where the NDVI suffered a decrease of 0.4-0.5. From Figure 17b it can be clearly seen the difference between areas with unaffected vegetation (shades of green) and agricultural land where the defoliation of the vegetation is enormous, so that the land seems to be bare of vegetation, appearing in shades of brown.

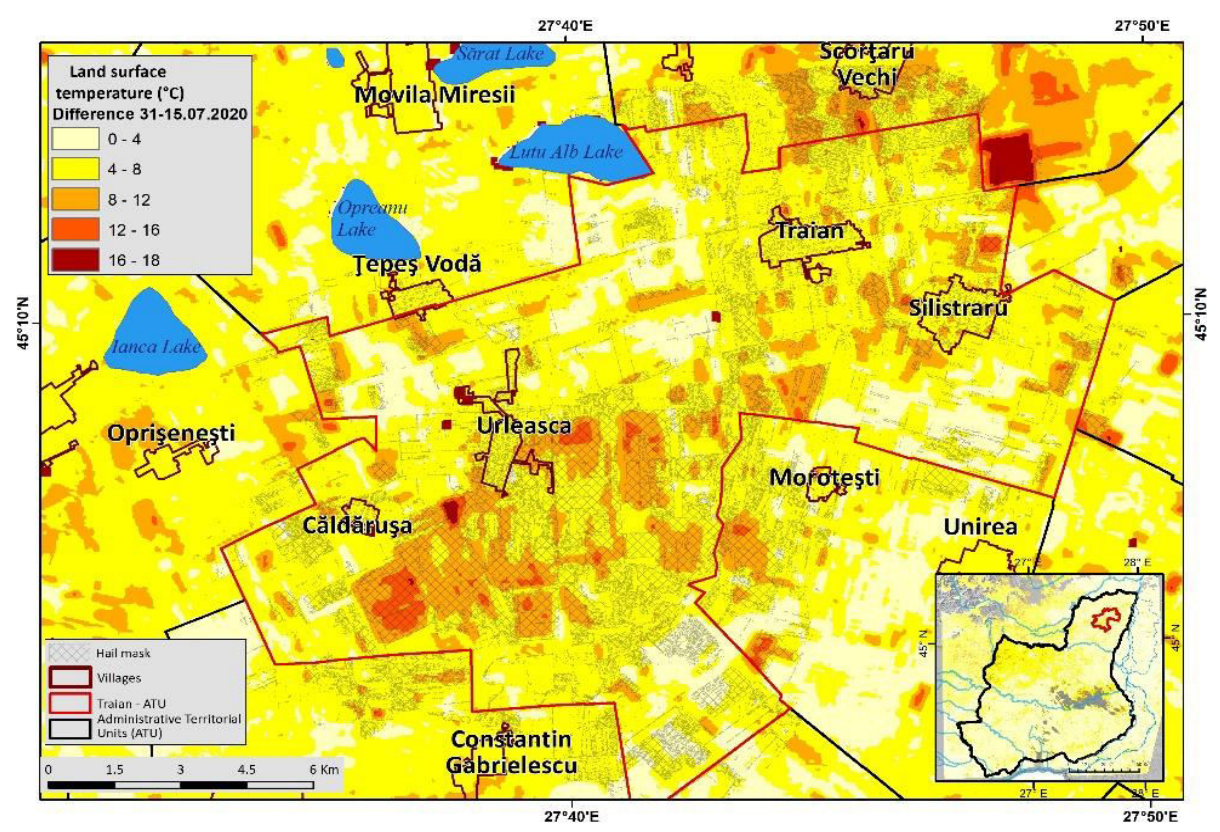

Fig. 16 LST difference between 15 and 31 July 2020 
For sun flower and corn areas, the LST difference were of $8.18^{\circ} \mathrm{C}$ and $8.14^{\circ} \mathrm{C}$ respectively, higher than the soybean that recorded a growth of $5.30^{\circ} \mathrm{C}$. Besides, it should be noted that for the undamaged areas of Traian a LST growth of $5.73^{\circ} \mathrm{C}$ was observed, so the degree of damage to the vegetation influenced the local growth change of land 370 temperature.
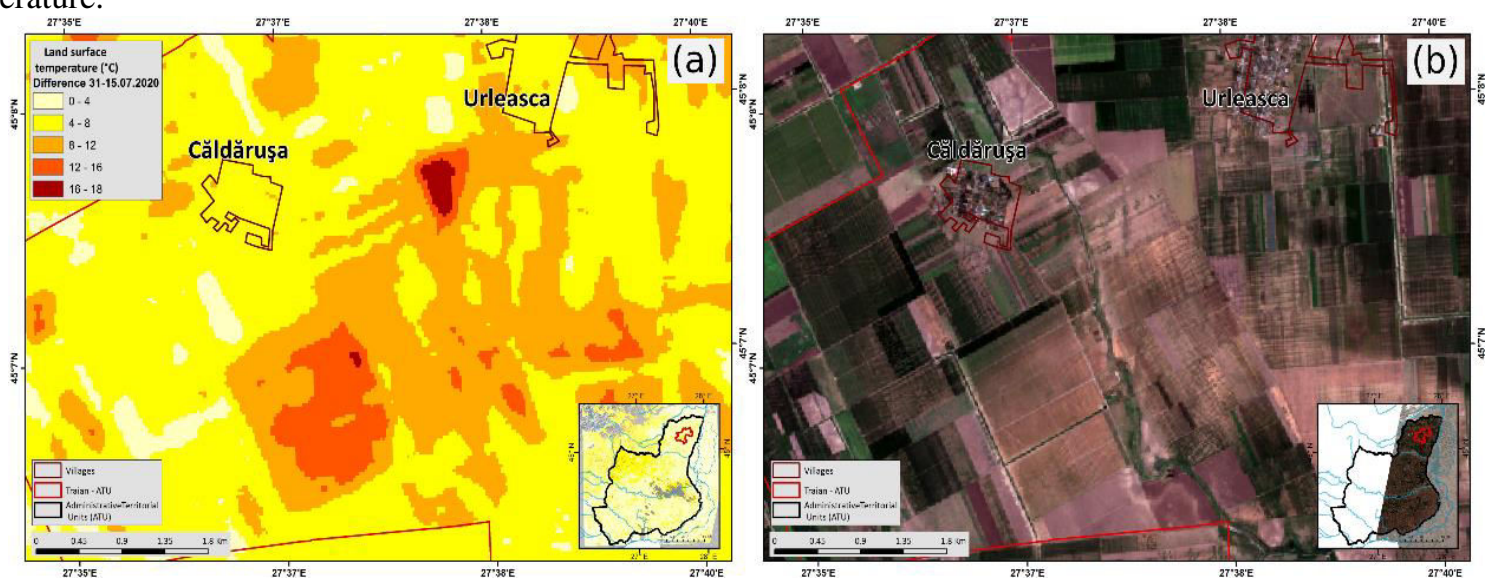

Fig. 17 (a) LST difference between 15 and 31 July and (b) Natural color image from 31 July 2020

\subsection{WHI}

The areas most affected by the hail have registered the lowest values, suggesting an extreme vegetative stress for the crops from the west of the Traian commune, crops that had optimal conditions for growth and high productivity before the hail event. Thus, for the period 28 July-04 August, the VHI values around the Căldăruşa village indicated an extreme agricultural drought, followed by the severe and moderate drought (Fig. 18).
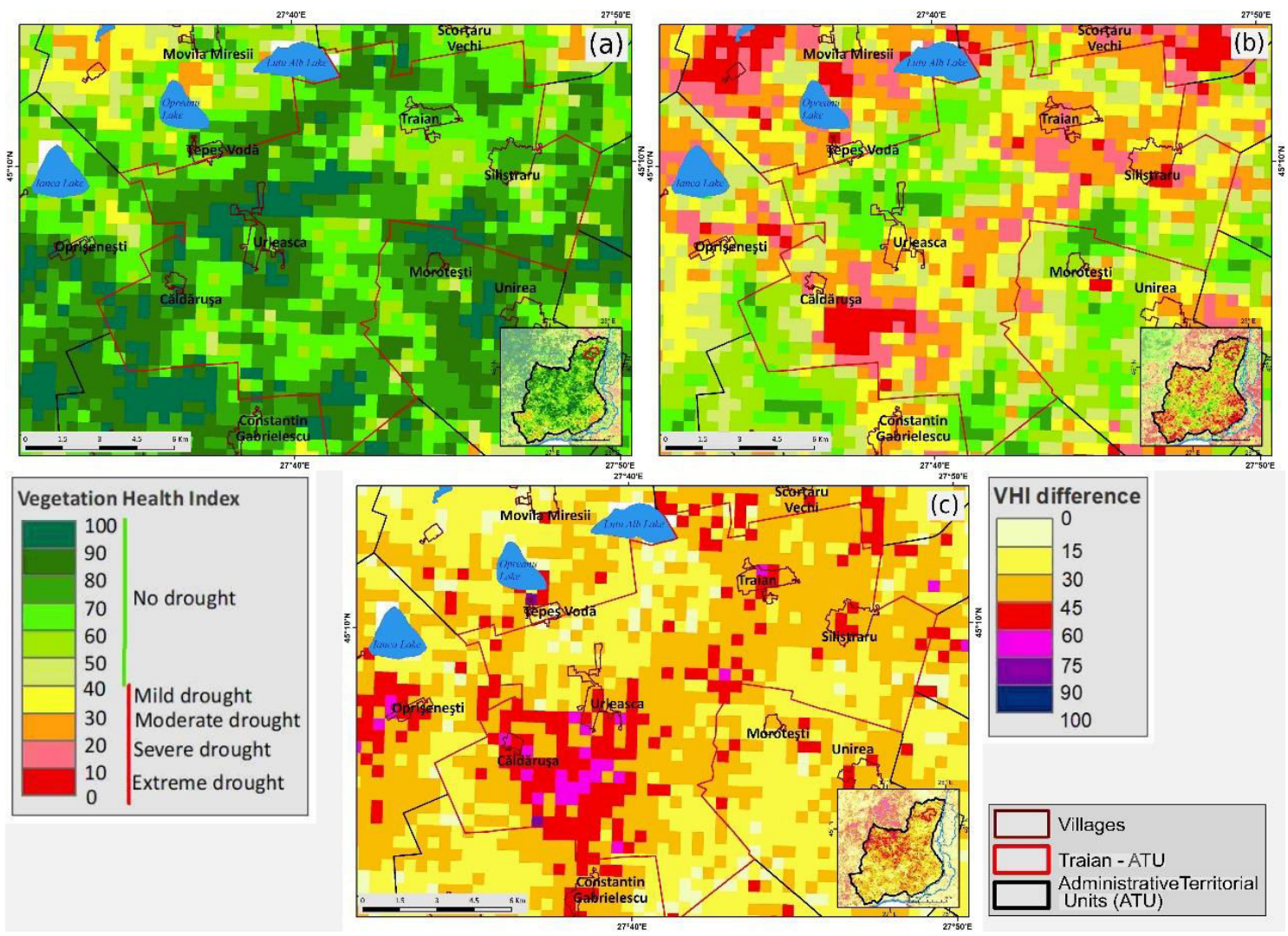

Fig. 18 VHI evolution: (a) 20-27 July 2020; (b) 27July-04 August 2020; (c) VHI decreasing (\%) after the difference between the VHI from the synthesis 201(20-27 July 2020 and 209 (28 July-04 August 2020); 
The hail effects on VHI are noted just in the case of synthesis 28 July-04 August because in the previous synthesis (20-27 July 2020), the maximum of NDVI, respectively the mean LST necessary for Terra MODIS products are recorded around the time 09:30 UTC, long before the hail occurred (12 UTC).

During the 21 days of recorded and processed data, the VHI surprised very well the remarkable decreasing trend of vegetation affected by the hail in the Traian commune. So, if the mean of VHI for the NDVI hail mask was 72 in the case of synthesis 201 (20-27 July), for the next synthesis (28 July-04 August) the VHI decreased to 41 (Fig. 19).

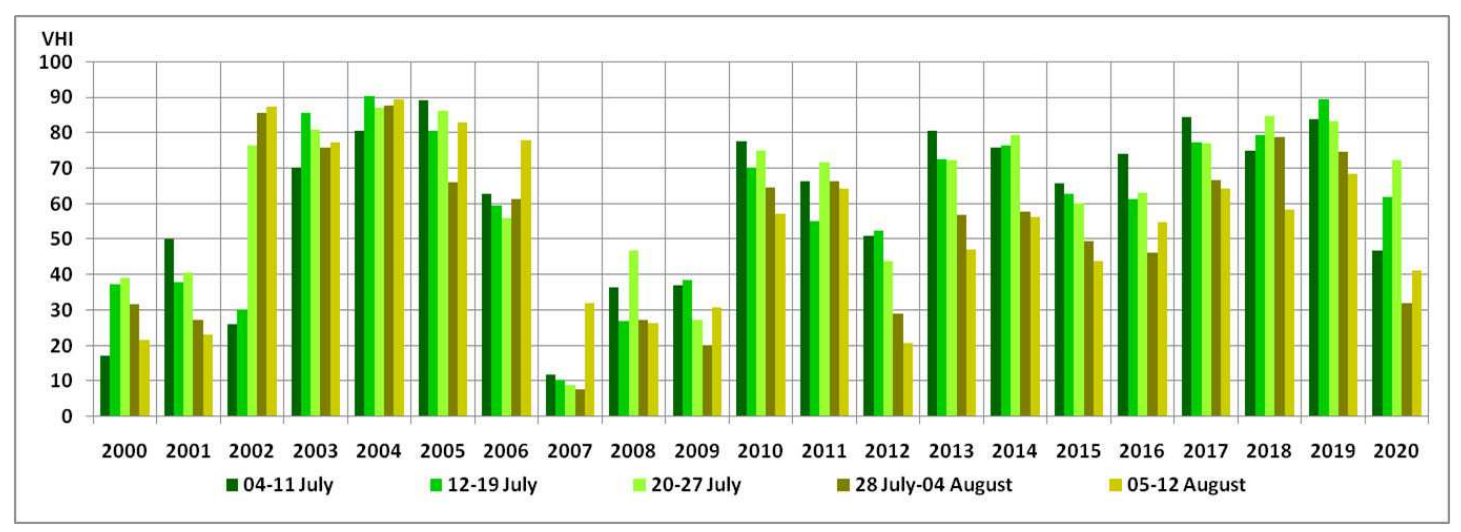

Fig. 19 VHI values for the Traian NDVI hail mask for the interval 04 July-12 August 2000-2020

The presence of hail effects on the crops is obviously visible through the dramatic loss of VHI with $40 \%$ in the case of VHI difference made between the synthesis 20-27 July 2020 and 28 July-04 August for the Traian hail mask (Fig. 20).

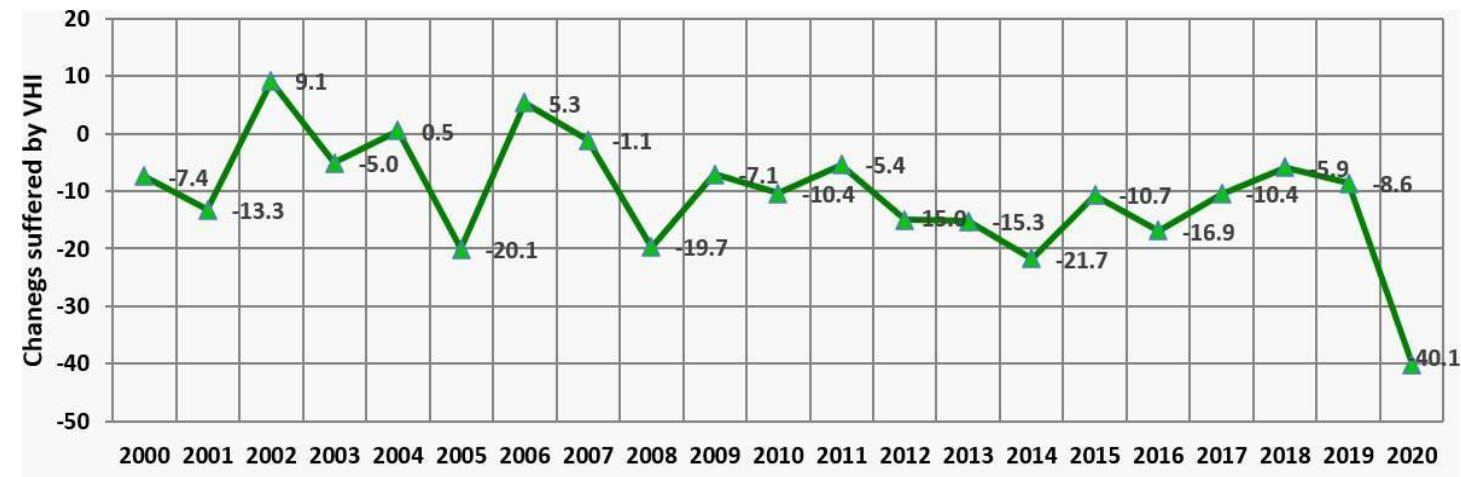

-VHI difference between synthesis 20-27 July and 28 July-04 August

Fig. 20 VHI changes after the difference between the synthesis 20-27 July and 28 July-04 August 2020 for the Traian hail mask

\subsection{Sentinel-1}

In the case of Sentinel-1 data, we tried to identify a homogeneous hail mask through Normalized Ratio Procedure between Bands (NRPB) and the difference between bands in dual polarization (eg. $\mathrm{VH}$ ) and bands in single polarization (eg. VV) but we could not find out satisfactory results. Therefore, we selected and processed to linear gamma only the band VV which is vertically in dual polarization (Fig. 21).

On 21 July, after the hail occurred the maximum of VV $(0.35 \mathrm{~dB})$ was recorded, then on the next available radar data (25 July), the affected surfaces registered a significant decrease, reaching the $0.26 \mathrm{~dB}$. Further, the VV values were oscillated around $0.20 \mathrm{~dB}$ (Fig. 22). 

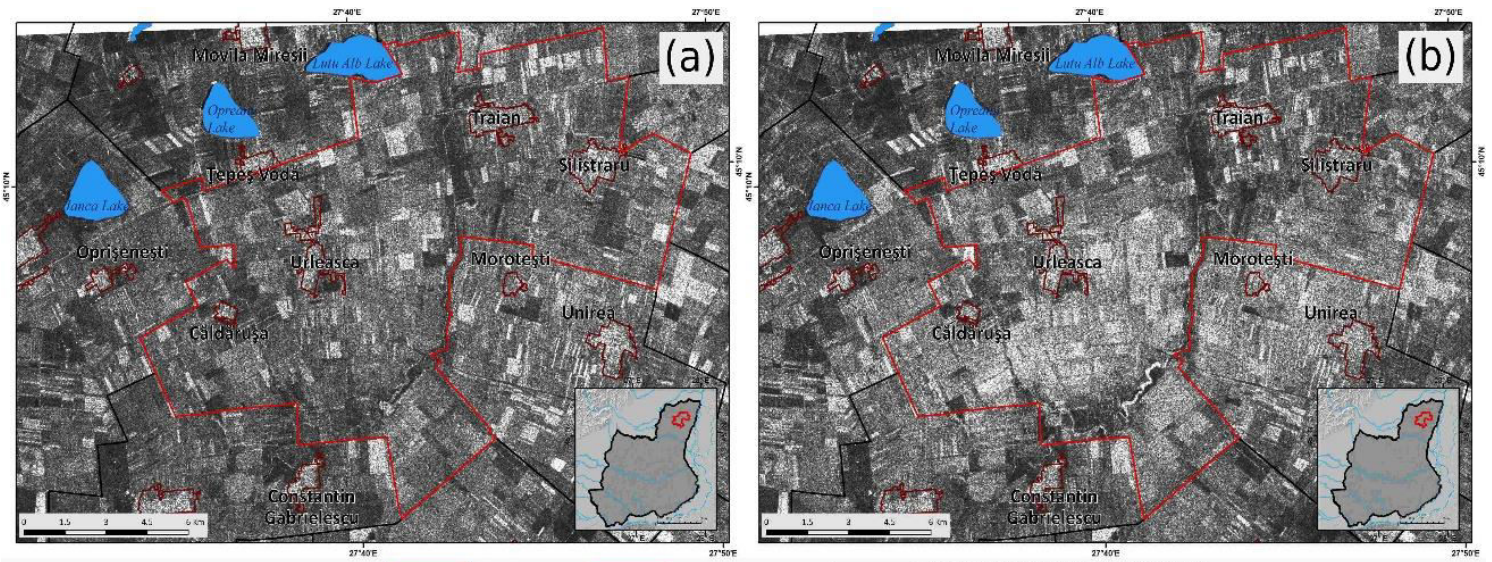

Traian - ATU

Units (ATU)

Fig. 21 VV linear gamma for Traian: (a) 14 July; (b) 21 July 2021

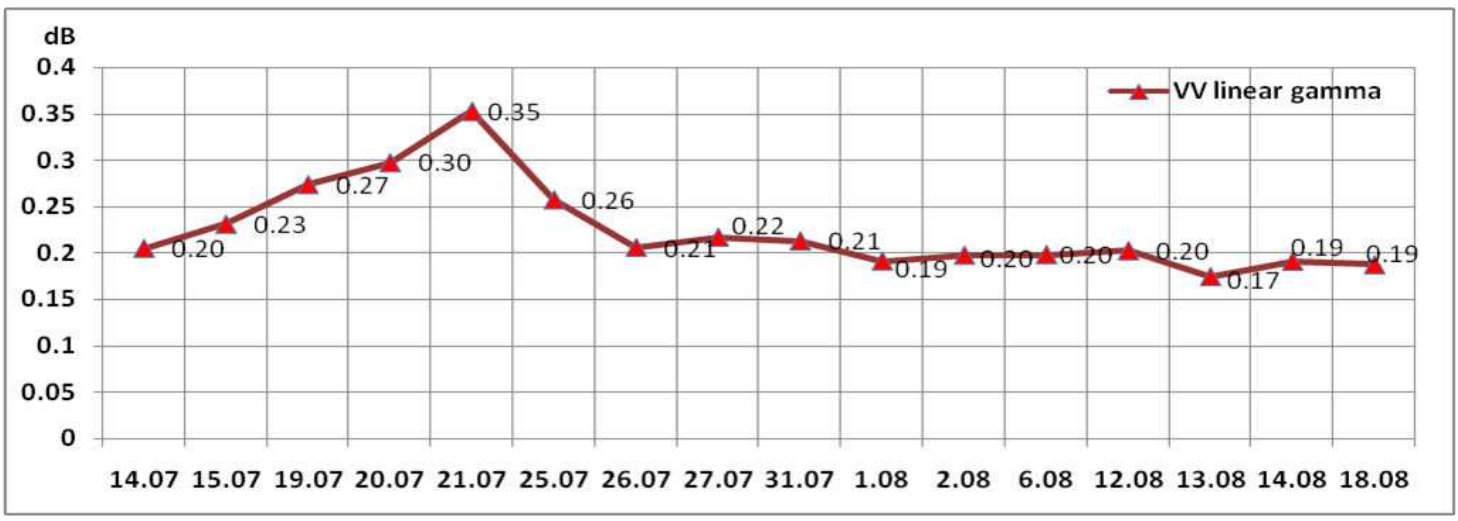

Fig. 22 VV linear gamma for the Traian hail mask

\section{6. $S W I$}

In the case of the SWI analysis, from the 8 levels at which the soil moisture is calculated, the depth of $2 \mathrm{~cm}$ most hailstorm on 20 July. It can be noticed that on 22 July, the humidity recorded at a depth of $2 \mathrm{~cm}$ decreased substantially, below the first pre-hail day, so that from 23 July to be below the other depth levels, thus confirming the infiltration of precipitation inside the soil (Fig. 23).

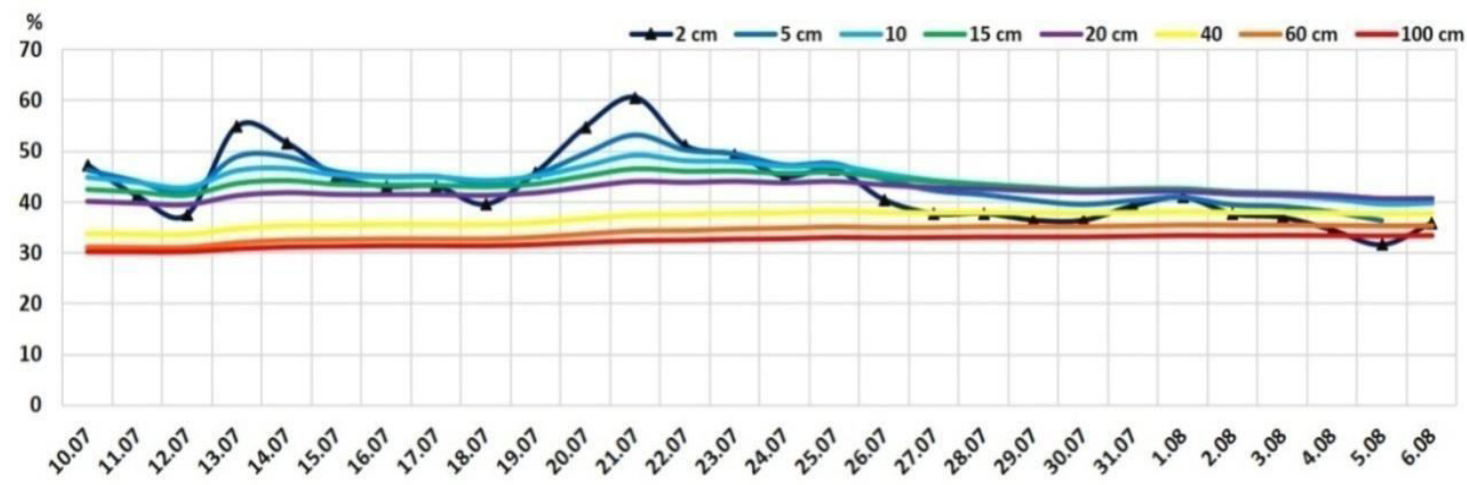

Fig. 23 SWI values between 10 July and 6August 2020 for Traian hail mask 
To emphasize the temporal correlation of the NDVI index, respectively of the resulting hail mask, with SWI, the humidity data at the depth of $2 \mathrm{~cm}$ from 14 and 21 July were analyzed based on the values difference. Thereby, the increase of humidity predominated, the most significant increases (15-20\%) being in the area of Urleasca and Căldăruşa, while in the east of Traian commune were reported increases of up to $5 \%$.

The overlap of the NDVI hail mask with the SWI situation confirms that the phenomenon occurred mainly in the west of the analyzed area (Fig. 24). Regarding the 14-21 July difference for the SWI values converted to volumetric units, soil moisture increases were higher south of the Căldăruşa and around Urleasca village (0.010-0.012), compared to the rest of the affected territory (Fig. 25). Also, the evolution of converted SWI (Fig. 26) reveals an important increase of soil moisture at $2 \mathrm{~cm}\left(\right.$ up to $0.21 \mathrm{~m}^{3} / \mathrm{m}^{3}$ ) for $21 \mathrm{July}$, after the hail. From 21 July, soil moisture is marked by a continuous decreasing trend.

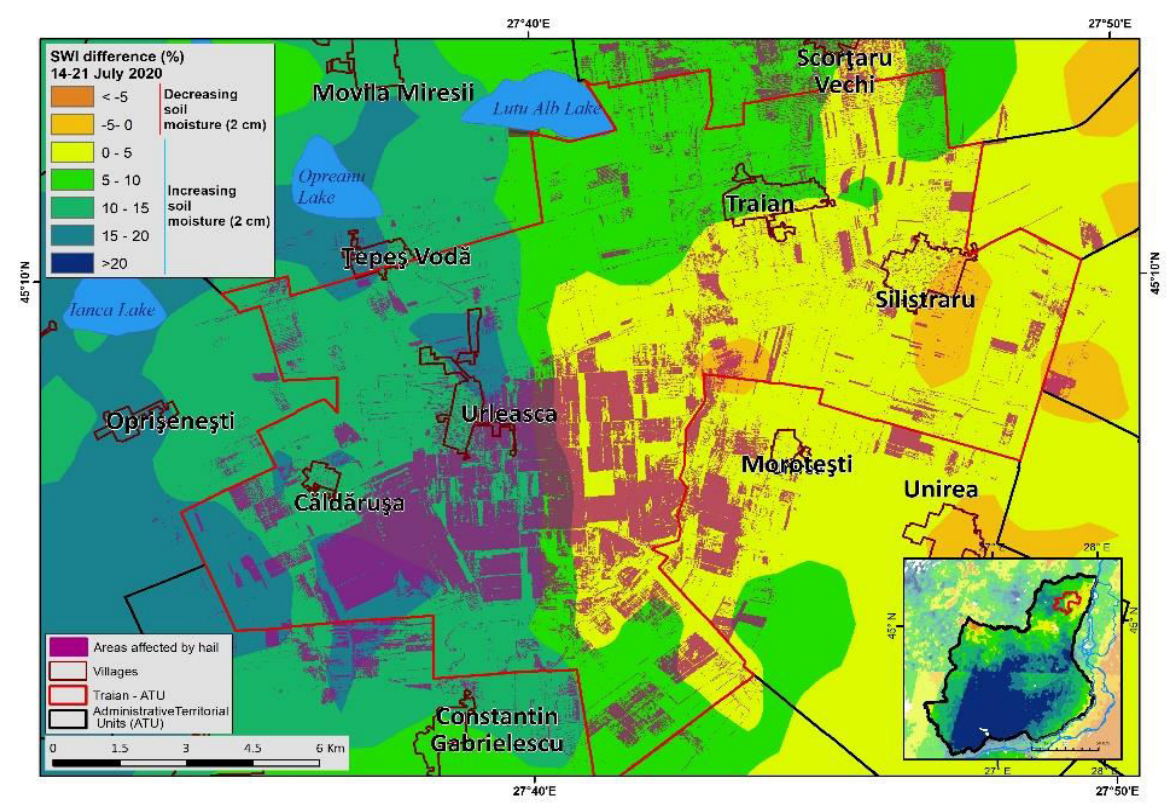

Fig. 24 SWI difference (\%) 14-21 July and the hail mask from NDVI

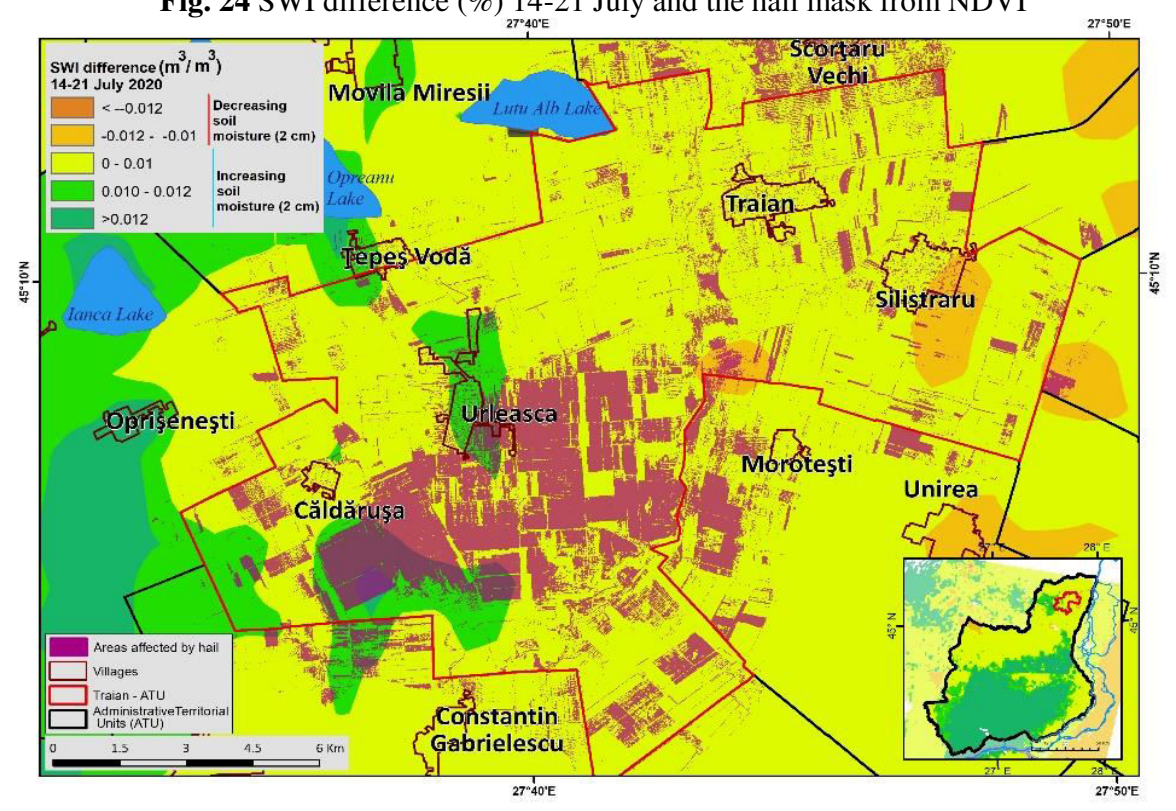

Fig. 25 SWI difference (m3/m3) 14-21 July and the hail mask from NDVI 


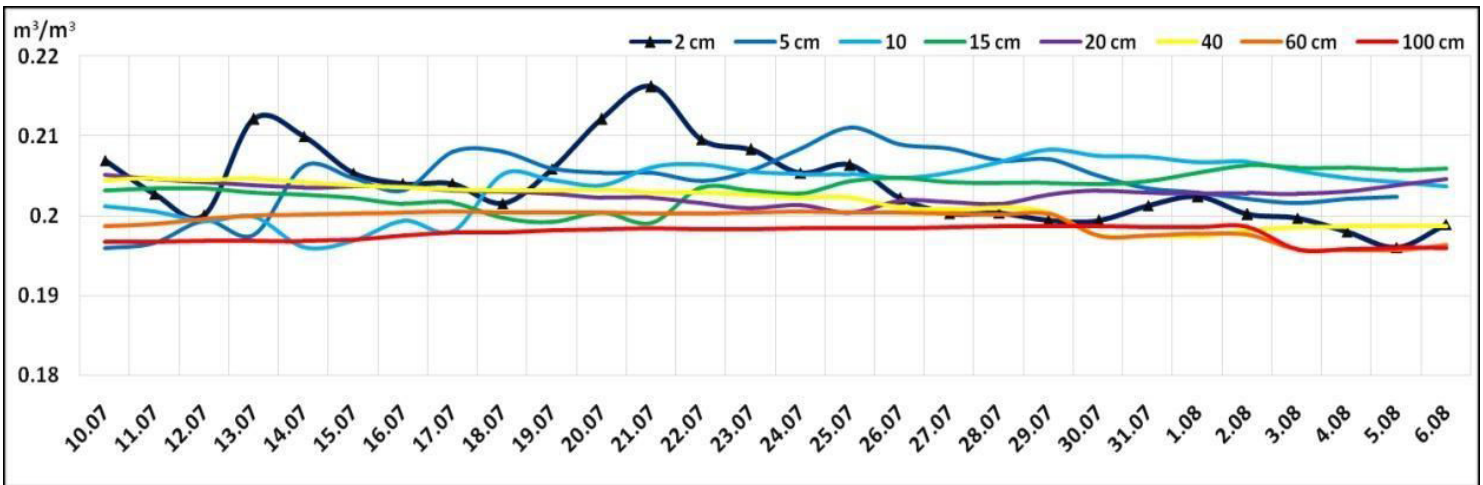

Fig. 26 SWI (m3/m3) values between 10 July and 6 August 2020 for Traian hail mask

\subsection{Weather Radar}

The hailstorm that occurred on 20 July 2021 in the study area was also analyzed and validated through the data from the Medgidia weather radar. The convective storm formed south-west of the study area, with approximately 1.5 hours earlier before reaching Traian commune. The speed of movement estimated from the weather radar data was around $35 \mathrm{~km} / \mathrm{h}$, intensifying just before reaching the affected area. Very high reflectivity values (>65 dBZ) were observed, indicating the presence of very large hail (approx. $5 \mathrm{~cm}$ ) within the cloud moments before entering the study area. Nevertheless, over the the affected area, although the maximum reflectivity values were greater that 60 dBZ, the radar algorithms estimated a hail size of about $2.5 \mathrm{~cm}$, which is still severe (Carbunaru et al. 2014; Cică et al. 2015).

The areal extent of decreased NDVI values corresponded well to the spatial extent of the hail identified in the radar data. The radar reflectivity image recorded at 12:07 UTC at a tilt angle of the radar antenna of $0.5^{\circ}(1.8 \mathrm{~km}$ altitude above ground) surprised a maximum of $66 \mathrm{dBZ}$ in the area of Căldăruşa village, high values $(60 \mathrm{dBZ})$ being also recorded in the next time sequence, at 12:13 UTC, Urleasca village being the most prone to hail (Fig. 27).

From Fig.27 one can observe how the hail moved from the west of Urleasca to the southeast, affecting Unirea commune as well, especially the Moroteşti village.
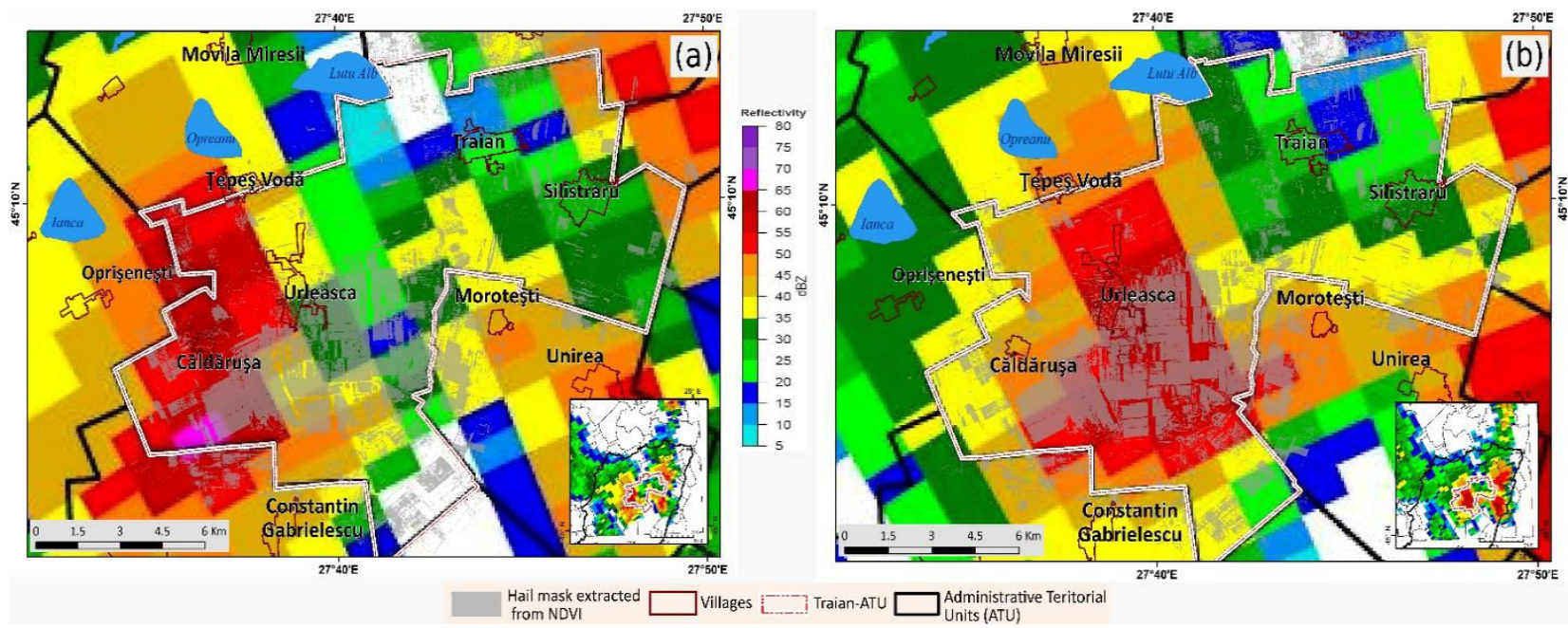

Fig. 27 Medgidia radar reflectivity from: (a) 2020.07.20, time 12:07 UTC; (b) 2020.07.20, time 12:13 UTC, tilt angle 0.5 ${ }^{\circ}$

\section{Conclusions}

Hail is a dangerous weather phenomenon, causing significant damage to agriculture. Modern weather radars allow the identification of hail, while high-resolution multispectral satellite imagery have the ability to provide valuable assistance in analyzing damage resulting from severe hail events. 
2 images, the spatial resolution of $10 \mathrm{~m}$ representing a great advantage in detecting and analyzing the vegetation affected by hail. It should also be emphasized that Sentinel-2 data was the only tool capable of identifying hail damage to vegetation. The 0.05 threshold applied for $\triangle$ NDVI and $\Delta$ LAI emphasizes better the hail damage extent compared to the simple positive difference $\triangle$ NDVI and $\Delta$ LAI. Also, comparing the results based on Otsu's method, it turned out that the identification of the spatial extent of hail is considerably limited for LAI comparing to NDVI, the latter overestimating the hail extent. According to the NDVI difference values (14-21 July 2020) higher than 0.05 , it was found that about 4000 ha were affected by hail, the arable lands registering the most damages (3550 ha), especially in the proximity of Căldărușa and Urleasca localities.

Given the results obtained by the two methods ( $\triangle$ NDVI and $\triangle \mathrm{LAI}$, followed by a visual subjective hail threshold, respectively the Binary Thresholding Function) one can conclude that the hail affected especially the agricultural areas from Urleasca and Căldăruşa and overall, the hail produced damages between 2000 and 4000 ha.

Considering that NDVI hail mask extent, based on the visual threshold, is more suitable than the LAI, we chose to compare several indices evolution (LAI, LST, SWI) with the extend derived from 0.05 NDVI threshold, in order to evaluate the hail damages. Another reason why we chose NDVI as hail mask for further several analyzes, instead of LAI, is the fact that NDVI has been widely used for the hail analysis.

The evolution of LAI and NDVI losses for the soybean after the hail event highlights the idea that soybean was less affected and the process of biophysical degradation was not so significant as in the case of corn and sunflower.

The differences between the LST values, from 15 to 31 July 2020, are higher than in the surrounding areas, with temperature increases, generally between $8-12^{\circ} \mathrm{C}$. The average LST for the affected area was $38.27^{\circ} \mathrm{C}$ on 31 July, compared to $30.48^{\circ} \mathrm{C}$ on $15 \mathrm{July}, 2020$, thus marking a difference of $+7.79^{\circ} \mathrm{C}$. At the same time, it was observed that the intensity of hail damage was directly proportional to the LST values. Thus, the LST difference values higher than $12^{\circ} \mathrm{C}$ were in the areas where the NDVI suffered a decrease of 0.4-0.5.

Based on the SWI difference at a depth of $2 \mathrm{~cm}$ from July 14 and 21, it was observed that the most significant increases (15-20\%) were in the area of Urleasca and Căldăruşa localities, while in the east of Traian commune was a moderate increase, up to at 5\%. The overlap of the hail mask extracted from NDVI with the SWI situation confirms that the hail occurred especially in the west of the analyzed area, which is also highlighted by the weather radar data. The use of images and remote sensing techniques allow the identification, analysis and evaluation of the hail phenomenon, providing continuous information. Sentinel-1,2 satellite data and products distributed free through the Copernicus service are an alternative data source and complementary to in-situ observations (which provide punctual information) or field observations, made after recording the phenomenon (time and resource consuming).

Author Contributions: Conceptualization, C.-V.A., I.O and A.I.; Data curation, C.-V.A.; Formal analysis, C.-V.A..; Methodology, C.-V.A., I.O. and A.I.; Software, C.-V.A., I.O and S.B.; Supervision, A.I.; Visualization, A.I.; Writing-original draft, C.-V.A.; Writing-review \& editing, C.-V.A., I.O. and S.B. All author shave read and agreed to the published version of the manuscript.

\section{Acknowledgements}

The authors thank Mr. Alexandru Dumitrescu for the daily gridded precipitation data used in the hail analysis. Special thanks are addressed to Mr. Cristi Mihalache (the author of the hail photos) for the photos use permission.

Conflicts of Interest: The authors declare no conflict of interest.

\section{Funding}

This research did not receive any specific grant from funding agencies in the public, commercial, or not-for-profit sectors.

\section{References}

Agrointeligenta (2020) Culturile agricole distruse de grindină. Fermier: În 20 de minute, gheaţa ne-a terminat tot! https://agrointel.ro/150677/cadere-grindina-judetul-braila/

Ahmed B, Kamruzzaman MD, Zhu X, et al (2013) Simulating land cover changes and their impacts on land surface temperature in dhaka, bangladesh. Remote Sens 5:5969-5998. https://doi.org/10.3390/rs5115969

Allen JT, Tippett MK, Kaheil Y, et al (2017) An extreme value model for U.S. hail size. Mon Weather Rev 145:4501-4519. https://doi.org/10.1175/MWR-D-17-0119.1

Angearu CV, Ontel I, Boldeanu G, et al (2020) Multi-temporal analysis and trends of the drought based on modis data in agricultural areas, romania. Remote Sens 12:1-24. https://doi.org/10.3390/rs12233940

Asrar G, Fuchs M, Kanemasu ET, Hatfield JL (1984) Estimating Absorbed Photosynthetic Radiation and Leaf Area Index from Spectral Reflectance in Wheat1. Agron J 76:300-306. 
Balteanu D, Alexe R (2001) Hazarde naturale şi antropogene. Corint, Bucharest

Bell J, Molthan A (2016) Evaluation of approaches to identifying hail damage to crop vegetation using satellite imagery. J Oper Meteorol 04:142-159. https://doi.org/10.15191/nwajom.2016.0411

Bell JR (2015) The Development of a Near-Real Time Hail Damage Swath Identification Algorithm for Vegetation. 133

Bell JR, Gebremichael E, Molthan AL, et al (2020) Complementing optical remote sensing with synthetic aperture radar observations of hail damage swaths to agricultural crops in the central United States. J Appl Meteorol Climatol 59:665-685. https://doi.org/10.1175/JAMC-D-19-0124.1

Bentley ML, Mote TL, Thebpanya P (2002) Using landsat to identify thunderstorm damage in agricultural regions. Bull Am Meteorol Soc 83:. https://doi.org/10.1175/1520-0477-83.3.363

Brown TM, Pogorzelski WH, Giammanco IM (2015) Evaluating hail damage using property insurance claims data. Weather Clim Soc 7:197-210. https://doi.org/10.1175/WCAS-D-15-0011.1

Burcea S, Cică R, Bojariu R (2016) Hail climatology and trends in Romania: 1961-2014. Mon Weather Rev 144:4289-4299. https://doi.org/10.1175/MWR-D-16-0126.1

Carbunaru DV, Sasu M, Burcea S, Bell A (2014) Detection of hail through the three-body scattering signatures and its effects on radar algorithms observed in Romania. Atmosfera 27:21-34. https://doi.org/10.1016/S01876236(14)71098-7

Changnon SA (1967) Areal-Temporal Variations of Hail Intensity in Illinois. J Appl Meteorol 6:536-541

Cică R (2018) Monitorizarea și evaluarea riscului asociat căderilor de grindină din sudul României. University of Bucharest

Cică R, Burcea S, Bojariu R (2015) Assessment of severe hailstorms and hail risk using weather radar data. Meteorol Appl 22:746-753. https://doi.org/10.1002/met.1512

Drusch M (2005) Observation operators for the direct assimilation of TRMM microwave imager retrieved soil moisture. Geophys Res Lett 32:L15403. https://doi.org/10.1029/2005GL023623

EOSDIS (2020) Earthdata

ESA (2017) Copernicus Open Access Hub

ESA (2020) https://step.esa.int/main/toolboxes/snap/

Felix MO, Kennedy P (2007) Correlation of polarimetric radar hail signature with MODIS satellite ground truth data. 87th AMS Annu Meet

Ferma (2020) Grindină brutală în județul Brăila: peste șase mii de hectare afectate. https://www.revistaferma.ro/noutati-companii/grindina-brutala-in-judetul-braila-peste-sase-mii-de-hectare-afectate

Gallo K, Smith T, Jungbluth K, Schumacher P (2012) Hail swaths observed from satellite data and their relation to radar and surface-based observations: a case study from Iowa in 2009. Weather Forecast 27:796-802. https://doi.org/10.1175/WAF-D-11-00118.1

Gross D (2005) No TitleMonitoring Agricultural Biomass Using NDVI Time Series. Food Agric Organ United Nations (FAO), Roma, Ital

H SAF (2020) Soil Water Index

Henebry GM, Ratcliffe IC (2002) Occurrence and Persistence of Hailstreaks in the Vegetated Land Surface. 131937

Hillaker HJ, Waite PJ (1985) Crop-Hail Damage in the Midwest Corn Belt. J Appl Meteorol Climatol 24:3-15. https://doi.org/10.1175/1520-0450(1985)024<0003:CHDITM>2.0.CO;2

Hoogewind KA, Baldwin ME, Trapp RJ (2017) The impact of climate change on hazardous convective weather in the United States: Insight from high-resolution dynamical downscaling. J Clim 30:10081-10100. https://doi.org/10.1175/JCLI-D-16-0885.1

Jackson RD, Reginato RJ, Idso SB (1977) Wheat canopy temperature: A practical tool for evaluating water requirements. Water Resour Res 13:651-656. https://doi.org/https://doi.org/10.1029/WR013i003p00651

Jedlovec GJ, Nair U, Haines SL (2006) Detection of storm damage tracks with EOS data. Weather Forecast 21:249267. https://doi.org/10.1175/WAF923.1

Jimenez-Munoz JC, Cristobal J, Sobrino JA, et al (2009) Revision of the Single-Channel Algorithm for Land Surface Temperature Retrieval From Landsat Thermal-Infrared Data. IEEE Trans Geosci Remote Sens 47:339-349. https://doi.org/10.1109/TGRS.2008.2007125

Jiménez-Muñoz JC, Sobrino JA, Skoković D, et al (2014) Land Surface Temperature Retrieval Methods From Landsat-8 Thermal Infrared Sensor Data. IEEE Geosci Remote Sens Lett 11:1840-1843. https://doi.org/10.1109/LGRS.2014.2312032

Josevski N, Sandvik A, Jones C, et al (2013) Analysis of Damage Caused to Vehicle Body Panels by Impacting Hail and Various Tools and Objects. SAE Int J Passeng Cars - Mech Syst 6:956-984. 
https://doi.org/https://doi.org/10.4271/2013-01-1438

Junghänel T, Brendel C, Winterrath T, Walter A (2016) Towards a radar- and observation-based hail climatology for Germany. Meteorol Zeitschrift 25:435-445. https://doi.org/10.1127/metz/2016/0734

Klimowski BA, Hjelmfelt MR, Bunkers MJ, et al (1998) Hailstorm damage observed from the GOES-8 satellite: The 5-6 July 1996 butte-meade storm. Mon Weather Rev 126:831-834. https://doi.org/10.1175/15200493(1998)126<0831:HDOFTG>2.0.CO;2

Kogan FN (1995) Application of vegetation index and brightness temperature for drought detection. Adv Sp Res 15:91-100. https://doi.org/10.1016/0273-1177(95)00079-T

Kogan FN (2001) Operational space technology for global vegetation assessment. Bull Am Meteorol Soc 82:19491964. https://doi.org/10.1175/1520-0477(2001)082<1949:OSTFGV>2.3.CO;2

Kunz M, Kugel PIS (2015) Detection of hail signatures from single-polarization C-band radar reflectivity. Atmos Res 153:565-577. https://doi.org/10.1016/j.atmosres.2014.09.010

LIU WT, KOGAN FN (1996) Monitoring regional drought using the Vegetation Condition Index. Int J Remote Sens 17:2761-2782. https://doi.org/10.1080/01431169608949106

Liu Y, de Jeu RAM, van Dijk AIJM, Owe M (2007) TRMM-TMI satellite observed soil moisture and vegetation density (1998-2005) show strong connection with El Niño in eastern Australia. Geophys Res Lett 34:1-5. https://doi.org/10.1029/2007GL030311

Liu YY, Parinussa RM, Dorigo WA, et al (2011) Developing an improved soil moisture dataset by blending passive and active microwave satellite-based retrievals. Hydrol Earth Syst Sci 15:425-436. https://doi.org/10.5194/hess-15-425-2011

Ma'rufah U, Hidayat R, Prasasti I (2017) Analysis of relationship between meteorological and agricultural drought using standardized precipitation index and vegetation health index. In: IOP Conf. Ser.: Earth Environ

Molthan A, Burks J, McGrath K, LaFontaine F (2013) Multi-sensor examination of hail damage swaths for near realtime applications and assessment. J Oper Meteorol 1:144-156. https://doi.org/10.15191/nwajom.2013.0113

Myneni RB, Ramakrishna R, Nemani R, Running SW (1997) Estimation of global leaf area index and absorbed par using radiative transfer models. IEEE Trans Geosci Remote Sens 35:1380-1393. https://doi.org/10.1109/36.649788

Octavia B, Niculescu E (1999) Riscurile climatice din România. Romanian Academy, Bucharest

Otsu N, Smith PL, Reid DB, et al (1979) Otsu_1979_otsu_method. IEEE Trans Syst Man Cybern C:62-66

Parastatidis D, Mitraka Z, Chrysoulakis N, Abrams M (2017) Online global land surface temperature estimation from landsat. Remote Sens 9:1-16. https://doi.org/10.3390/rs9121208

Parker MD, Ratcliffe IC, Henebry GM (2005) The July 2003 Dakota hailswaths: Creation, characteristics, and possible impacts. Mon Weather Rev 133:1241-1260. https://doi.org/10.1175/MWR2914.1

Peters AJ, Griffin SC, Viña A, Ji L (2000) Use of remotely sensed data for assessing crop hail damage. PE\&amp;RS, Photogramm Eng \&amp; Remote Sens 66:1349-1355

Prabhakar M, Gopinath KA, Reddy AGK, et al (2019) Mapping hailstorm damaged crop area using multispectral satellite data. Egypt J Remote Sens Sp Sci 22:73-79. https://doi.org/10.1016/j.ejrs.2018.09.001

Prein AF, Holland GJ (2018) Global estimates of damaging hail hazard. Weather Clim Extrem 22:10-23. https://doi.org/10.1016/j.wace.2018.10.004

Púcik T, Castellano C, Groenemeijer P, et al (2019) Large hail incidence and its economic and societal impacts across Europe. Mon Weather Rev 147:3901-3916. https://doi.org/10.1175/MWR-D-19-0204.1

Radio Romania Antena Satelor (2020) Culturi şi grădini de legume, distruse de grindină într-o jumătate de oră. https://www.antenasatelor.ro/fermier-in-romania/actualitatea-agricola/40099-culturi-si-gradini-de-legume,distruse-de-grindina-intr-o-jumatate-de-ora.html;https://agrointel.ro/150677/cadere-grindina-judetulbraila/;https://www.ziarulprofit.ro/index.php/su

Reichle RH, Koster RD, Dong J, Berg AA (2004) Global soil moisture from satellite observations, land surface models, and ground data: Implications for data assimilation. J Hydrometeorol 5:430-442. https://doi.org/10.1175/1525-7541(2004)005<0430:GSMFSO>2.0.CO;2

Rouse J. W. J, Haas R H., Schell J A., Deering D W. (1974) Monitoring Vegetation Systems in the Great Plains with Erts. In: NASA Special Publication. p 309

Sandu I, Mateescu E, Vătămanu VV (2010) Schimbări climatice în România şi efectele sale asupra agriculturii. Siteh, Craiova

Sandu I, Pescaru VI, Poiană I (2008) Clima Romaniei. Romanian Academy, Bucharest

Sarvia F, De Petris S, Borgogno-Mondino E (2020) A Methodological Proposal to Support Estimation of Damages from Hailstorms Based on Copernicus Sentinel 2 Data Times Series BT - Computational Science and Its Applications - ICCSA 2020. In: Gervasi O, Murgante B, Misra S, et al. (eds). Springer International 
Publishing, Cham, pp 737-751

Schiesser HH (1990) Hailfall: the relationship between radar measurements and crop damage. Atmos Res 25:559582. https://doi.org/10.1016/0169-8095(90)90038-E

Schuster SS, Blong RJ, McAneney KJ (2006) Relationship between radar-derived hail kinetic energy and damage to insured buildings for severe hailstorms in Eastern Australia. Atmos Res 81:215-235. https://doi.org/10.1016/j.atmosres.2005.12.003

Song L, Liu S, Kustas WP, et al (2015) Using the surface temperature-albedo space to separate regional soil and vegetation temperatures from ASTER data. Remote Sens 7:5828-5848. https://doi.org/10.3390/rs70505828

Towers PC, Strever A, Poblete-Echeverría C (2019) Comparison of vegetation indices for leaf area index estimation in vertical shoot positioned vine canopies with and without grenbiule hail-protection netting. Remote Sens 11:. https://doi.org/10.3390/rs11091073

Towery NG, Eyton JR, Changnon SAJ, Christine LD (1975) REMOTE SENSING OF CROP HAIL DAMAGE. 6:65-94

Tucker CJ (1979) Red and photographic infrared linear combinations for monitoring vegetation. Remote Sens Environ 8:127-150. https://doi.org/10.1016/0034-4257(79)90013-0

Valsan M (2020) Natura s-a dezlantuit in judetul Braila / Grindina a facut prapad. Info Braila

Wang L, Wen M, Li P, et al (2020) Growth and yield responses of drip-irrigated cotton to two different methods of simulated hail damages. Arch Agron Soil Sci 1-13. https://doi.org/10.1080/03650340.2020.1789967

WMO (2018) (World Meteorological Organization), Guidelines on the Defintion and Monitoring of Extreme Weather and Climate Events. Task Team Defin Extrem Weather Clim Events 62

Yu X, Guo X, Wu Z (2014) Land surface temperature retrieval from landsat 8 TIRS-comparison between radiative transfer equation-based method, split window algorithm and single channel method. Remote Sens 6:98299852. https://doi.org/10.3390/rs6109829

Yue Y, Zhou L, Zhu A-X, Ye X (2019) Vulnerability of cotton subjected to hail damage. PLoS One 14:e0210787. https://doi.org/10.1371/journal.pone.0210787

Ziarul Profit (2020) Sute de hectare de recolte au fost distruse de grindină în județul Brăila. https://www.ziarulprofit.ro/index.php/sute-de-hectare-de-recolte-au-fost-distruse-de-grindina-in-judetul-braila/ (2020) Remote Sensing Lab. In: http://rslab.gr/downloads_LandsatLST.html 